\title{
A comparison of HONO budgets for two measurement heights at a field station within the boreal forest in Finland
}

\author{
R. Oswald ${ }^{1,2}$, M. Ermel ${ }^{1,2}$, K. Hens ${ }^{3}$, A. Novelli ${ }^{3}$, H. G. Ouwersloot ${ }^{3,4}$, P. Paasonen ${ }^{5}$, T. Petäjä ${ }^{5}$, M. Sipilä ${ }^{5}$, \\ P. Keronen ${ }^{5}$, J. Bäck ${ }^{6}$, R. Königstedt ${ }^{3}$, Z. Hosaynali Beygi ${ }^{3}$, H. Fischer ${ }^{3}$, B. Bohn ${ }^{7}$, D. Kubistin ${ }^{3,8}$, H. Harder ${ }^{3}$, \\ M. Martinez ${ }^{3}$, J. Williams ${ }^{3}$, T. Hoffmann ${ }^{2}$, I. Trebs ${ }^{1,9}$, and M. Sörgel ${ }^{1}$ \\ ${ }^{1}$ Biogeochemistry Department, Max Planck Institute for Chemistry, P.O. Box 3060, 55020 Mainz, Germany \\ ${ }^{2}$ Institute for Inorganic and Analytical Chemistry, Johannes Gutenberg University Mainz, 55128 Mainz, Germany \\ ${ }^{3}$ Airchemistry Department, Max Planck Institute for Chemistry, 55128 Mainz, Germany \\ ${ }^{4}$ Meteorology and Air Quality, Wageningen University, Wageningen, the Netherlands \\ ${ }^{5}$ Department of Physics, University of Helsinki, P.O. Box 64, 00014 Helsinki, Finland \\ ${ }^{6}$ Department of Forest Sciences, University of Helsinki, P.O. Box 27, 00014 Helsinki, Finland \\ ${ }^{7}$ Institut für Energie- und Klimaforschung IEK-8: Troposphäre, Forschungszentrum Jülich GmbH, \\ 52428 Jülich, Germany \\ ${ }^{8}$ University of Wollongong, School of Chemistry, Wollongong, Australia \\ ${ }^{9}$ Luxembourg Institute of Science and Technology, Environmental Research and Innovation (ERIN) \\ Department, 5 avenue des Hauts-Fourneaux, 4362 Esch/Alzette, Luxembourg
}

Correspondence to: M. Sörgel (m.soergel@mpic.de)

Received: 28 February 2014 - Published in Atmos. Chem. Phys. Discuss.: 21 March 2014

Revised: 10 November 2014 - Accepted: 25 November 2014 - Published: 23 January 2015

\begin{abstract}
Atmospheric concentrations of nitrous acid (HONO), one of the major precursors of the hydroxyl radical $(\mathrm{OH})$ in the troposphere, significantly exceed the values predicted by the assumption of a photostationary state (PSS) during daytime. Therefore, additional sources of HONO were intensively investigated in the last decades. This study presents budget calculations of HONO based on simultaneous measurements of all relevant species, including $\mathrm{HONO}$ and $\mathrm{OH}$ at two different measurement heights, i.e. $1 \mathrm{~m}$ above the ground and about 2 to $3 \mathrm{~m}$ above the canopy ( $24 \mathrm{~m}$ above the ground), conducted in a boreal forest environment. We observed mean HONO concentrations of about $6.5 \times 10^{8}$ molecules $\mathrm{cm}^{-3}$ (26 ppt) during daytime, more than 20 times higher than expected from the PSS of $0.2 \times 10^{8}$ molecules $\mathrm{cm}^{-3}$ ( $\left.1 \mathrm{ppt}\right)$. To close the budgets at both heights, a strong additional source term during daytime is required. This unidentified source is at its maximum at noon (up to $1.1 \times 10^{6}$ molecules $\mathrm{cm}^{-3} \mathrm{~s}^{-1}, 160 \mathrm{ppt} \mathrm{h}^{-1}$ ) and in general up to 2.3 times stronger above the canopy than close to the ground. The insignificance of known gas phase reactions and other processes like dry deposition or advec-
\end{abstract}

tion compared to the photolytic decomposition of $\mathrm{HONO}$ at this measurement site was an ideal prerequisite to study possible correlations of this unknown term to proposed HONO sources. But neither the proposed emissions from soils nor the proposed photolysis of adsorbed $\mathrm{HNO}_{3}$ contributed substantially to the unknown source. However, the unknown source was found to be perfectly correlated to the unbalanced photolytic loss of HONO.

\section{Introduction}

Since the first unequivocal detection of HONO in the atmosphere by Perner and Platt (1979), its formation and fate, as well as its contribution to primary $\mathrm{OH}$ production, have been intensively studied (Lammel and Cape, 1996; Kleffmann, 2007). Recently, the importance of HONO in atmospheric chemistry and its implications have been demonstrated using a global chemistry transport model (Elshorbany et al., 2012). While the fate of HONO is mainly determined by the photolytic decomposition producing $\mathrm{OH}$, the major uncertainty 
in modelling studies results from the lack of understanding of the HONO formation pathways. Budget calculations of the postulated sources and sinks (Kleffmann et al., 2005; Su et al., 2008b; Sörgel et al., 2011a) have usually been used to quantify the magnitude of the missing source term. Only a few source estimates derived from flux measurements have been published up to now (Zhang et al., 2012; Zhou et al., 2011; Ren et al., 2011). The current status of HONO formation and loss pathways, important for atmospheric chemistry, is as follows.

The major sink during daytime for HONO is the homolytic cleavage of the O-N single bond by radiation $(\lambda<400 \mathrm{~nm})$, determined by the photolysis frequency, $J(\mathrm{HONO})$.

$\mathrm{HONO} \stackrel{h v}{\longrightarrow} \mathrm{OH}+\mathrm{NO}$

Since $\mathrm{OH}$ is produced, this reaction is of primary importance to atmospheric photochemistry. $J(\mathrm{HONO})$ shows a similar wavelength dependency as the photolysis frequency of nitrogen dioxide $\left(\mathrm{NO}_{2}\right), J\left(\mathrm{NO}_{2}\right)$ (Kraus and Hofzumahaus, 1998). Therefore $J(\mathrm{HONO})$ can be linked to $J\left(\mathrm{NO}_{2}\right)$ using the approach of Trebs et al. (2009):

$J(\mathrm{HONO})=0.17 \times J\left(\mathrm{NO}_{2}\right)$.

The back reaction of (R1) in presence of a third body can reform HONO with a rate constant ( $k_{2}$ at $298 \mathrm{~K}$ and $1013 \mathrm{hPa}$ ) of $(7.4 \pm 1.3) \times 10^{-12} \mathrm{~cm}^{3}$ molecules ${ }^{-1} \mathrm{~s}^{-1}$ (Reaction R2) (Sander et al., 2011).

$\mathrm{OH}+\mathrm{NO} \stackrel{M}{\rightarrow} \mathrm{HONO}$

While the gas phase reaction of $\mathrm{OH}$ with $\mathrm{NO}$ forms $\mathrm{HONO}, \mathrm{OH}$ may also react with $\mathrm{HONO}$ and reform $\mathrm{NO}_{\mathrm{x}}$.

$\mathrm{HONO}+\mathrm{OH} \rightarrow \mathrm{NO}_{2}+\mathrm{H}_{2} \mathrm{O}$

Since concentrations of $\mathrm{HONO}$ and $\mathrm{OH}$ are generally much lower than those of NO, Reaction (R3) has less influence on HONO cycling than Reaction (R2), although the reaction rate constant $\left(k_{3}\right.$ at $298 \mathrm{~K}$ and $1013 \mathrm{hPa}$ ) of about $6.0 \times 10^{-12} \mathrm{~cm}^{3}$ molecules ${ }^{-1} \mathrm{~s}^{-1}$ is similar (Atkinson et al., 2004). Hence, the turnover is low and contributes typically less than $5 \%$ to the total HONO loss (Su et al., 2008b; Sörgel et al., 2011a).

A surface reaction of $\mathrm{NO}_{2}$ and $\mathrm{H}_{2} \mathrm{O}$ was suggested as another formation pathway for HONO. Finlayson-Pitts et al. (2003) proposed a mechanism whereby $\mathrm{NO}_{2}$ is dimerized and then dissolved in a humid surface film. The formed $\mathrm{N}_{2} \mathrm{O}_{4}$ rearranges into the mixed anhydride of nitrous acid and nitric acid $\left(\mathrm{ONONO}_{2}\right)$, which rapidly dissolves into $\mathrm{HONO}$ and nitrate.

$2 \mathrm{NO}_{2}(\mathrm{~g})+\mathrm{H}_{2} \mathrm{O}(\mathrm{l}) \rightarrow \mathrm{HONO}(\mathrm{g})+\mathrm{H}^{+}(\mathrm{aq})+\mathrm{NO}_{3}^{-}(\mathrm{aq})$

Yabushita et al. (2009) and De Jesus Medeiros and Pimentel (2011) further investigated the mechanism with focus on the
$\mathrm{NO}_{2}$ uptake and the kinetics of the initial hydrolysis. The reaction rate constant of Reaction (R4) is difficult to determine in the field but can be estimated with the approach of Alicke et al. (2002).

$k_{4}^{\text {dark }}=\frac{[\mathrm{HONO}]_{\text {max }}-[\mathrm{HONO}]_{\text {sunset }}}{\left(t_{\text {max }}-t_{\text {sunset }}\right) \times \overline{\left[\mathrm{NO}_{2}\right]_{t_{\text {sunset }}}^{t_{\max }}}}$

After sunset, the concentration of HONO ([HONO $]_{\text {sunset }}$ ) increases and reaches a maximum $\left([\mathrm{HONO}]_{\max }\right)$. The difference between $[\mathrm{HONO}]_{\max }$ and $[\mathrm{HONO}]_{\text {sunset }}$ divided by the product of the elapsed time $\left(t_{\max }-t_{\text {sunset }}\right)$ and the average $\mathrm{NO}_{2}$ concentration during that time $\left(\overline{\left[\mathrm{NO}_{2}\right]_{t_{\text {sunset }}}^{t_{\max }}}\right)$ determines the rate of heterogeneous $\mathrm{HONO}$ formation during the night. The reaction rates found for night-time conversion range from 0.4 (Kleffmann et al., 2003) to $2.0 \mathrm{ppb}(\mathrm{HONO}) \times$ $\mathrm{ppb}\left(\mathrm{NO}_{2}\right)^{-1} \times \mathrm{h}^{-1}$ (Sörgel et al., 2011a). This approach is only valid if the heterogeneous dark Reaction (R4) is the dominant source of $\mathrm{HONO}$ during the night.

Besides the dark reaction of $\mathrm{NO}_{2}$, ortho-nitrophenols (oNPs) can photolytically decompose to form $\mathrm{HONO}$ as a side product (Bejan et al., 2006).

o-NPs $\stackrel{h v}{\longrightarrow}[\text { products }]^{*}+\mathrm{HONO}$

The authors propose parts of the reaction mechanism, but since they could not measure the main products, the exact and complete mechanism is not yet clarified. It is further stated that this source might be of primary interest for the atmosphere under urban conditions, where possibly $1 \mathrm{ppb}$ of o-NPs occurs. Since the o-NPs absorb light in a similar wavelength range as $\mathrm{NO}_{2}$, it is possible to estimate the photolysis frequency (in $\mathrm{s}^{-1}$ ) of o-NPs $(J(\mathrm{o}-\mathrm{NPs}))$ based on measured relative photolysis frequencies of HONO formation from oNPs and $\mathrm{NO}_{2}$ (Bejan et al., 2006). This approach gives an upper limit for HONO formation from o-NPs. $J\left(\mathrm{NO}_{2}\right)$ can be substituted by $J(\mathrm{HONO})$ according to Eq. (1).

$J(\mathrm{o}-\mathrm{NPs})=2.5 \times 10^{-3} \times J\left(\mathrm{NO}_{2}\right)=1.4 \times 10^{-2}$

$\times J(\mathrm{HONO})$

In addition to the reaction of $\mathrm{NO}_{2}$ with surface-adsorbed water (R4), Stemmler et al. (2006) and (2007) found that a surface film or aerosol of humic acid (HA) can act as a photosensitiser when irradiated and reduces $\mathrm{NO}_{2}$ to HONO.

$\mathrm{HA} \stackrel{h v}{\longrightarrow} \mathrm{A}^{\text {red }}+\mathrm{X}^{\mathrm{ox}}$
$\mathrm{A}^{\mathrm{red}}+\mathrm{X}^{\mathrm{ox}} \rightarrow \mathrm{HA}^{\prime}$
$\mathrm{A}^{\mathrm{red}}+\mathrm{NO}_{2} \rightarrow \mathrm{HA}^{\prime \prime}+\mathrm{HONO}$

HA naturally occurs in the environment, for example in soil. Hence, soil might act as a source for HONO under irradiation in the UV and exposure to $\mathrm{NO}_{2}$ (Stemmler et al., 2006). Reactants other than $\mathrm{A}^{\text {red }}$ in reaction (R8) might also be reductive. For example, fresh soot particles are supposed to reduce $\mathrm{NO}_{2}$ and form HONO. This source is only important 
for high $\mathrm{NO}_{2}$ concentrations and environments with freshly emitted soot (Aubin and Abbatt, 2007; Monge et al., 2010).

It was shown by several studies (Kubota and Asami, 1985; Twigg et al., 2011; Su et al., 2011; Oswald et al., 2013) that soils can emit HONO. Decreasing soil water content leads to an increase in soil aeration with emission of trace gases, namely $\mathrm{N}_{2} \mathrm{O}$, NO and HONO. Due to the complexity of soil emission fluxes depending on biological, physical and chemical processes as well as on soil properties, it is not straightforward to calculate the source strength, although observed NO emissions might serve as a proxy for HONO emission fluxes (Oswald et al., 2013). Furthermore, the exchange of HONO between the soil and atmosphere may be influenced by the accumulation of deposited HONO at the soil surface and subsequent re-emission during the day (VandenBoer et al., 2013). This may lead to enhanced emission of HONO compared to laboratory-performed soil studies. Similarly, drying leaf surfaces can release HONO from evaporating dew (He et al., 2006), which constitutes another process related to drying surfaces.

Surface-adsorbed nitric acid $\mathrm{HNO}_{3}$ (ads) that is either deposited or directly formed during the reaction cascade of (R4) was proposed to be photolytically sensitive and might decompose to HONO in the UV (Zhou et al., 2011).

$$
\begin{aligned}
& \mathrm{HNO}_{3(\text { ads })} \stackrel{h v}{\longrightarrow}\left[\mathrm{HNO}_{3(\text { ads })}\right]^{*} \\
& {\left[\mathrm{HNO}_{3(\text { ads })}\right]^{*} \rightarrow \mathrm{HONO}_{(\text {ads })}+\mathrm{O}\left({ }^{3} \mathrm{P}\right)_{(\text {ads })}} \\
& \mathrm{HONO}_{(\text {ads })} \leftrightharpoons \mathrm{HONO}_{(\mathrm{g})}
\end{aligned}
$$

The production of $\mathrm{HONO}$ by photolysis of $\mathrm{HNO}_{3 \text { (ads) }}$ depends on the physico-chemical state of the surface. While for dry surfaces (relative humidity $(\mathrm{RH})=0 \%) \mathrm{NO}_{\mathrm{x}}$ is the major product, relative humidity of about $20 \%$ suffices to increase the HONO yield (Zhou et al., 2003). According to Goodman et al. (2001), at $20 \% \mathrm{RH}$ there should be at least one monolayer of water present at the surface. Zhou et al. (2003) further propose that $\mathrm{NO}_{2}$ (ads) formed during the photolysis

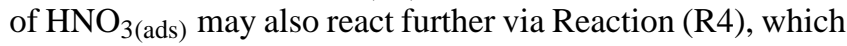
not only forms $\mathrm{HONO}$ but also recovers parts of $\mathrm{HNO}_{3}$. Later on, Zhou et al. (2011) suggested that the formed $\mathrm{NO}_{2}$ is reduced to HONO via the mechanism of Reactions (R6) and (R8) proposed by Stemmler et al. (2006). However, the rate of HONO formation depends on the amount of $\mathrm{HNO}_{3}$ available on irradiated surfaces and the photolysis frequency of adsorbed $\mathrm{HNO}_{3}, J\left(\mathrm{HNO}_{3}\right)$ ads, that is much higher than in the gas phase (Zhu et al., 2008; Zhu et al., 2010). Depending on the type of surface, the enhancement factor varies; Zhou et al. (2003) found an enhancement of about 2 orders of magnitude by $\mathrm{HNO}_{3}$ adsorption on borosilicate glass (see also Ramazan et al., 2004), while Baergen and Donaldson (2013) calculated an enhancement of about 4 orders of magnitude by $\mathrm{HNO}_{3}$ adsorbed to grime.

Other loss terms than Reactions (R1 and R3) include the dry and wet deposition of HONO. The dry deposition of HONO depends on the ambient mixing ratio of HONO, tur- bulent mixing within the planetary boundary layer and the ability of terrestrial surfaces to take up HONO. With a Henry coefficient of $49 \mathrm{M} \mathrm{atm}^{-1}$ (Park and Lee, 1988), wet deposition of HONO is quite efficient, especially for neutral to alkaline solutions (effective Henry coefficient). For example, mixing ratios of HONO strongly decrease after a rain event (Sörgel et al., 2011b).

Assuming only the known gas phase Reactions (R1 to R3) contribute to the HONO formation, a photostationary state should be established (Kleffmann et al., 2005):

$$
\begin{aligned}
& \frac{\mathrm{d}[\mathrm{HONO}]_{\mathrm{PSS}}}{\mathrm{d} t}=k_{2}[\mathrm{NO}][\mathrm{OH}] \\
& -J(\mathrm{HONO})[\mathrm{HONO}]_{\mathrm{PSS}}-k_{3}[\mathrm{OH}][\mathrm{HONO}]_{\mathrm{PSS}}=0 \\
& \Rightarrow[\mathrm{HONO}]_{\mathrm{PSS}}=\frac{k_{2}[\mathrm{NO}][\mathrm{OH}]}{J(\mathrm{HONO})+k_{3}[\mathrm{OH}]} .
\end{aligned}
$$

This equilibrium can only explain a minor portion of gas phase HONO observed at remote and rural sites (Kleffmann, 2007; Su et al., 2008b; Sörgel et al., 2011a; Wong et al., 2012) but may play an important role in measurement results obtained in urban areas (Lee et al., 2013). The budget calculations of Sörgel et al. (2011a) and Li et al. (2012) showed that including heterogeneous reactions of $\mathrm{NO}_{2}(\mathrm{R} 4)$ only slightly improves the discrepancy between $[\mathrm{HONO}]_{\mathrm{PSS}}$ and measured HONO mixing ratios.

In this study, we present the results of the field campaign HUMPPA-COPEC 2010 (Hyytiälä United Measurement of Photochemistry and Particles in Air - Comprehensive Organic Precursor Emission and Concentration study) related to HONO chemistry, and we provide a detailed overview of its sources and sinks using a budget calculation for two measurement heights, i.e. below and above a boreal forest canopy. We explicitly analyse additional source terms, such as HONO emission by soil and the formation of HONO by photolysis of $\mathrm{HNO}_{3 \text { (ads) }}$.

\section{Experimental}

The HUMPPA-COPEC 2010 was a comprehensively instrumented intensive field measurement campaign performed from 12 July to 12 August at the SMEAR II site (Station for Measuring Ecosystem-Atmosphere Relation; $61.846^{\circ} \mathrm{N}$, $24.295^{\circ} \mathrm{E}$ ) located in the boreal forest in Hyytiälä (Williams et al., 2011).

HONO was measured using two long path absorption photometer instruments (LOPAP, QUMA Elektronik \& Analytik, Wuppertal, Germany). A detailed description of the instrument has been given by Kleffmann et al. (2002) and Heland et al. (2001). Briefly, an acidic solution of sulfanilamide is used to sample HONO with a stripping coil. HONO is transformed rapidly into a diazonium salt, the precursor of diazotisation, carried out in sequence. The concentration of the azo dye formed is equivalent to the concentration of $\mathrm{HONO}$ in the sampled air and is measured by a VIS-photometer. 
Artefacts due to wall reactions are minimised in the LOPAP by using an external sampling unit where the derivatization takes place instead of using inlet lines. A short $(L=1.5 \mathrm{~cm})$ radiation-shielded glass inlet is the only instrument surface to which the sampling air is exposed before HONO is stripped in the first coil. The LOPAP uses two stripping coils in a series. Hence, potential interferences are accounted for by the quantitatively sampling of $\mathrm{HONO}$ in the first coil using a fast and specific reaction (Kleffmann et al., 2002; Heland et al., 2001). All interferences are assumed to react the same way in both coils and, therefore, the HONO detection can be corrected using the measured "artefact HONO" in the second coil. The background signal of the instrument was checked automatically for $30 \mathrm{~min}$ every $4 \mathrm{~h}$ using purified air. Consequently, all diurnal fluctuations of noise are monitored and considered in the evaluation of the results. The comparison of both LOPAP instruments used in this study has been described in detail by Sörgel et al. (2011b) and has shown a good agreement - within $12 \%$ under dry conditions (no rain or fog). The inlets of the two instruments were positioned at about 1 and $24 \mathrm{~m}$ above the ground (canopy top height 20 to $21 \mathrm{~m}$ ). Both instruments were operated with a response time of below $10 \mathrm{~min}$ and lower limit of detection ranging from 0.2 to 1.3 ppt during the campaign.

A laser-induced fluorescence (LIF) instrument measured the atmospheric concentration of the hydroxyl radical $(\mathrm{OH})$ based on the fluorescence assay by gas expansion technique (FAGE) (Hens et al., 2014; Novelli et al., 2014) at a height of about $24 \mathrm{~m}$ above the canopy, while a chemical ionisation mass spectrometer (CIMS; Petäjä et al., 2009) measured $\mathrm{OH}$ near to the ground at about $1 \mathrm{~m}$. Lower detection limits of LIF and CIMS were about $9 \times 10^{5}$ molecules $\mathrm{cm}^{-3}$ and $5 \times 10^{4}$ molecules $\mathrm{cm}^{-3}$ respectively. For a detailed description we refer to Hens et al. (2014).

$\mathrm{NO}$ and $\mathrm{NO}_{\mathrm{x}}$ were monitored by high-resolution and high-sensitivity chemiluminescence detectors: a TEI 42C TL (Thermo Fisher Scientific, US) with a limit of detection of about $0.1 \mathrm{ppb}$ positioned at $4 \mathrm{~m}$ and a modified (Hosaynali Beygi et al., 2011) CLD 790 SR with a detection limit of about $16 \mathrm{ppt}$ (ECO-Physics, Switzerland) positioned at $24 \mathrm{~m}$ above the ground. Both instruments use a blue-light converter for efficient and selective transformation of $\mathrm{NO}_{2}$ to NO. In addition, ozone $\left(\mathrm{O}_{3}\right)$ was measured by a UV-absorption photometer above the canopy.

The photolysis rates of $\mathrm{NO}_{2}$ and $\mathrm{O}_{3}$ and $J\left(\mathrm{NO}_{2}\right)$ and $J\left(\mathrm{O}^{1} \mathrm{D}\right)$ were measured using filter radiometers (Meteorologie consult, Königstein, Germany; Bohn et al., 2008). Two $J\left(\mathrm{NO}_{2}\right)$ sensors were positioned at $2 \mathrm{~m}$ and $24 \mathrm{~m}$ above the ground, and one $\mathrm{J}\left(\mathrm{O}^{1} \mathrm{D}\right)$ sensor was placed at $24 \mathrm{~m}$. Each measured the downwelling radiation. $J(\mathrm{HONO})$ was calculated from measured $J\left(\mathrm{NO}_{2}\right)$ according to Trebs et al. (2009).

Relative humidity, temperature, wind direction, wind speed and other meteorological parameters were monitored routinely by the SMEAR II station (Junninen et al., 2009; http://www.atm.helsinki.fi/smartSMEAR/).

Evaluation of the boundary layer height was determined by radiosondes, measuring relative humidity, temperature, pressure and altitude. From these data, vertical profiles of the potential temperature and the specific humidity were gained and used to infer the height and type of the boundary layer (Ouwersloot et al., 2012).

A sample from the O-horizon of soil was taken on 10 June 2012 at the measurement site and measured under controlled conditions in the lab according to Oswald et al. (2013) to investigate $\mathrm{NO}$ and $\mathrm{HONO}$ emission fluxes from soil.

\section{Results}

Some instruments were not running continuously during the measurement period of HUMMPA-COPEC 2010 from 12 July to 12 August 2010. Besides specific instrument malfunctions, several power disruptions caused by thunderstorms often interrupted the measurement. From 17 July to 5 August, the two LOPAP instruments were running about $30 \%$ of the time simultaneously. The data set of other measurements is close to complete for this period, except for the $\mathrm{OH}$ measurement above the canopy and the $J\left(\mathrm{NO}_{2}\right)$ measurement below the canopy (see Fig. 1).

Besides a linear relationship found between $\mathrm{OH}$ measured at the forest floor and above the canopy (Fig. 2), the exponential relationship of $J\left(\mathrm{NO}_{2}\right)$ at $2 \mathrm{~m}$ above the ground and $J\left(\mathrm{NO}_{2}\right)$ at $24 \mathrm{~m}$ above the ground was used to interpolate $\mathrm{OH}$ above the canopy and $J\left(\mathrm{NO}_{2}\right)$ below the canopy to extend the database for PSS calculations.

\subsection{Diel variation of HONO}

In the clean environment of Hyytiälä, diurnal variations of HONO were observed with mean daytime concentrations of $6.6 \times 10^{8}$ molecules $\mathrm{cm}^{-3}(27 \mathrm{ppt})$ at $1 \mathrm{~m}$ height and $6.5 \times 10^{8}$ molecules $\mathrm{cm}^{-3}(26 \mathrm{ppt})$ at $24 \mathrm{~m}$ height and mean night-time concentrations of $9.1 \times 10^{8}$ molecules $\mathrm{cm}^{-3}$ (37 ppt) at $1 \mathrm{~m}$ height and $9.2 \times 10^{8}$ molecules $\mathrm{cm}^{-3}$ (37 ppt) at $24 \mathrm{~m}$. Maximum values reached $3.2 \times 10^{9}$ molecules $\mathrm{cm}^{-3}$ (132 ppt) at $1 \mathrm{~m}$ and $3.4 \times 10^{9}$ molecules $\mathrm{cm}^{-3}(138 \mathrm{ppt})$ at $24 \mathrm{~m}$ at 22:30 in the late evening of 2 August. The concentrations reached a minimum after a short and strong rain event in the morning of 25 July with values below 2 ppt close to the detection limit. This underlines that, analogue to the observations of Sörgel et al. (2011a), no uncorrected interferences occur in clean air. The concentrations of HONO were calculated according to Eq. (5) by assuming a PSS only valid for conditions with the short photolytic lifetime of HONO. In agreement with Kleffmann et al. (2005) and Sörgel et al. (2011a), the box plots in Fig. 3 obviously show that for both heights the calculated concentrations are often more than 1 order of magnitude lower than the measured concen- 


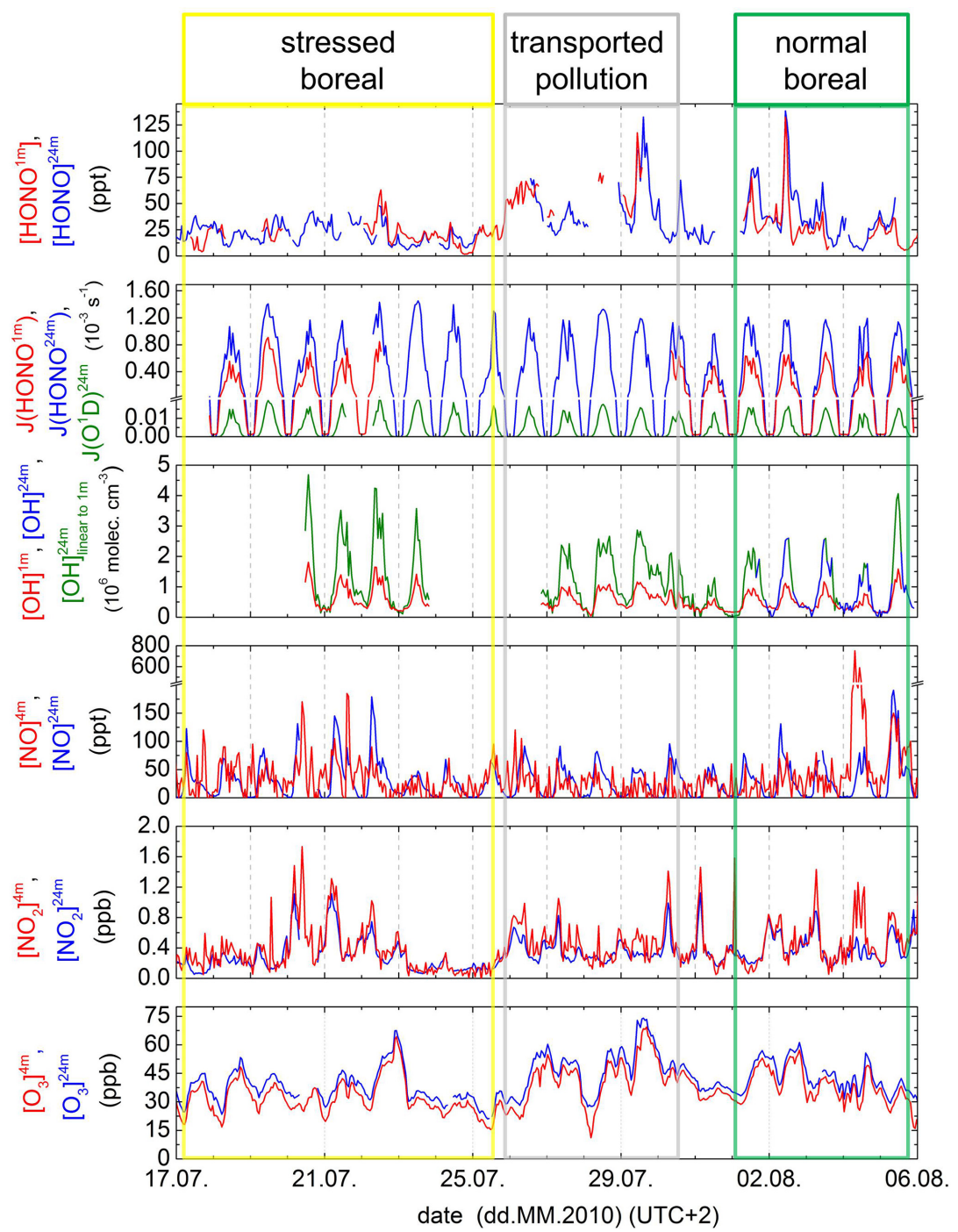

Figure 1. Overview of the measured concentration of different trace gases and the photolysis frequencies $J(\mathrm{HONO})$ and $J\left(\mathrm{O}^{1} \mathrm{D}\right)$. The linearly connected data points represent $60 \mathrm{~min}$ average values. Mixing ratios or concentrations are shown for the period where HONO was measured at both heights. $[\mathrm{OH}]_{\text {linear to }}^{24 \mathrm{~m}}$ was used to fill the gaps in $\mathrm{OH}$ measurements above the canopy (see Fig. 2a). Coloured boxes mark the respective regimes of "normal boreal" (green), "stressed boreal" (yellow) and "transported pollution" (grey).

tration of HONO. While the PSS calculation shows a peak in the morning (06:30) at $1 \mathrm{~m}$ height and around mid-morning (08:30) at $24 \mathrm{~m}$ height, the daytime measured HONO values peak at noon (11:30).

Sörgel et al. (2011a) stated that [HONO]PSS correlates best with measured [NO] and found neither a correlation to measured $[\mathrm{OH}]$ nor to measured $J(\mathrm{HONO})$. The correlation between $[\mathrm{HONO}]_{\mathrm{PSS}}$ and $[\mathrm{NO}]$ was also strong in our data (Fig. 4). The reasonable correlation of [HONO $]_{\text {PSS }}$ to measured $[\mathrm{NO}]$ might serve as a proxy for $[\mathrm{HONO}]_{\mathrm{PSS}}$ in general, since the ratio seems to be quite constant.

$\frac{[\mathrm{HONO}]_{\mathrm{PSS}}}{[\mathrm{NO}]}=\frac{k_{2}[\mathrm{OH}]}{J(\mathrm{HONO})+k_{3}[\mathrm{OH}]} \cong 0.02$
$J$ (HONO) at PSS shows values of about 2 orders of magnitude higher than $k_{2}$ or $k_{3}$ multiplied with the $[\mathrm{OH}]$. Since $\mathrm{OH}$ formation is strongly linked to radiation (Rohrer and Berresheim, 2006), its concentration positively correlates with $J(\mathrm{HONO})$. Therefore, NO drives the variability of the PSS.

\subsection{HONO budget calculations}

The two gas phase Reactions (R2 and R3) together with the photolysis fail to explain the observed HONO concentrations. The comparison of observed changes in HONO concentrations with calculated values, considering further sources and sinks, leads to a more complete understanding 

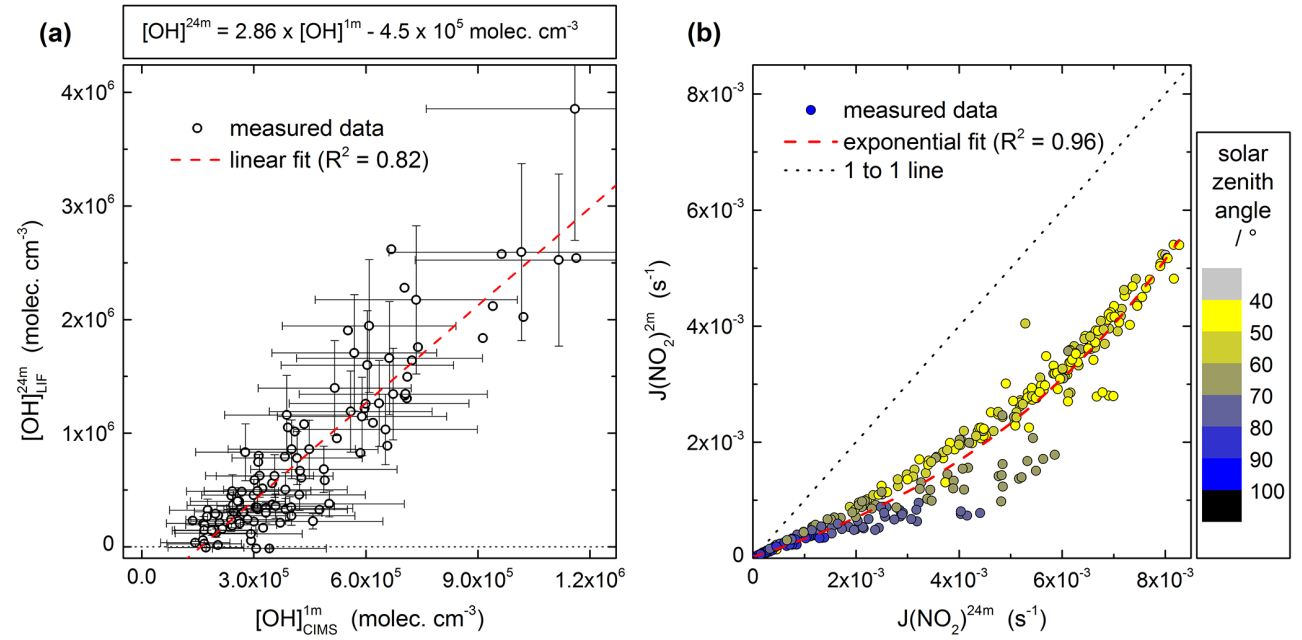

Figure 2. (a) The linear correlation of $\mathrm{OH}$ concentration below and above the canopy was used for interpolating data of $\mathrm{OH}$ concentration above the canopy. (b) Similar to (a), the exponential correlation of measured photolysis frequency below and above the canopy was used to interpolate data of $J\left(\mathrm{NO}_{2}\right)$ below the canopy. Colour code of dots represents the solar zenith angle. Additionally, the one-to-one line is shown as a dashed line.

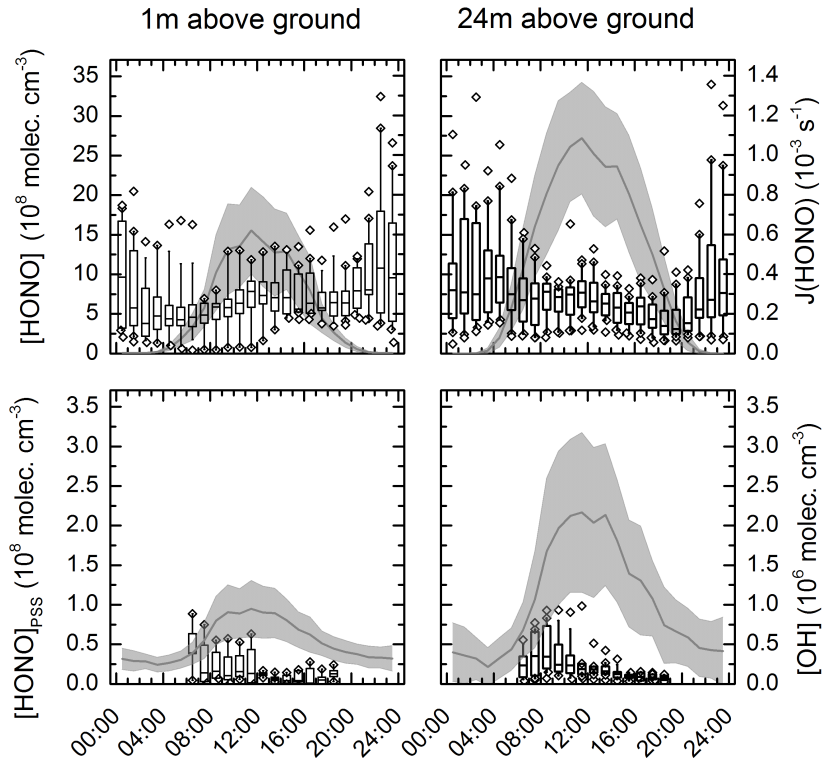

time (hh:mm UTC+2)

Figure 3. Upper panels show box plots of the diel cycle of HONO measured at $1 \mathrm{~m}$ and $24 \mathrm{~m}$ respectively and the average corresponding $J(\mathrm{HONO})$ with standard deviation (grey shaded line). Lower panels show box plots for the calculated PSS concentration of HONO for the heights of $1 \mathrm{~m}$ and $24 \mathrm{~m}$ respectively during daytime (lifetime of HONO below $4 \mathrm{~h}$ ) where PSS is possibly attained. Additionally, the average concentration of $\mathrm{OH}$ with standard deviation (grey shaded line) for the two respective heights is presented. The boxes represent the 25 to 75 percentile, the line within the box is the median, the bars show the 10 to 90 percentile and outliers are marked as open diamonds. of HONO cycling.

$$
\underbrace{\frac{\Delta[\mathrm{HONO}]}{\Delta t}}_{\text {observed }}=\underbrace{\text { Sources }- \text { Sinks }}_{\text {calculated budget }}
$$

If the calculated difference in sources and sinks equals the observed value, the budget would be closed. As mentioned before, normally an unknown source is missing, which can be calculated according to $\mathrm{Su}$ et al. (2008b) and Sörgel et al. (2011a) with the following equation:

$$
\begin{aligned}
P_{\text {unknown }}= & \underbrace{\frac{\Delta[\mathrm{HONO}]}{\Delta t}}_{\text {observed }}-\underbrace{k_{2}}_{\mathrm{R} 2: P_{\mathrm{NO}+\mathrm{OH}}[\mathrm{NO}][\mathrm{OH}]}-\underbrace{k_{4}^{\text {dark }}\left[\mathrm{NO}_{2}\right]}_{\mathrm{R} 4: P_{\mathrm{het}}} \\
& +\underbrace{J(\mathrm{HONO})[\mathrm{HONO}]}_{\mathrm{R} 1: L_{\mathrm{phot}}} \\
& +\underbrace{k_{3}[\mathrm{OH}][\mathrm{HONO}]}_{\mathrm{R} 3: L_{\mathrm{HONO}+\mathrm{OH}}}+\underbrace{\frac{v_{\mathrm{dep}}}{h_{\mathrm{BL}}}[\mathrm{HONO}]}_{\text {dry deposition: } L_{\mathrm{dep}}} \\
& +\underbrace{ \pm T_{\mathrm{h}} \pm T_{\mathrm{v}}}_{\text {horizontal and vertical transports }}
\end{aligned}
$$

The resulting $P_{\text {unknown }}$ shows that for most of the day there is still a large source missing (Fig. 5), at least for the period from 06:00 in the morning to 20:00 in the evening when HONO lifetimes are below $30 \mathrm{~min}$. This source is dominated by the photolytic loss of HONO, which forms the major sink for HONO and exceeds the considered sources by far. Due to generally low $\mathrm{NO}_{2}$ values (below $2 \mathrm{ppb}$ ), the contribution of the dark heterogeneous $\mathrm{NO}_{2}$ conversion $\left(P_{\text {het }}\right)$ is very low, except for the early morning (before 07:00). 


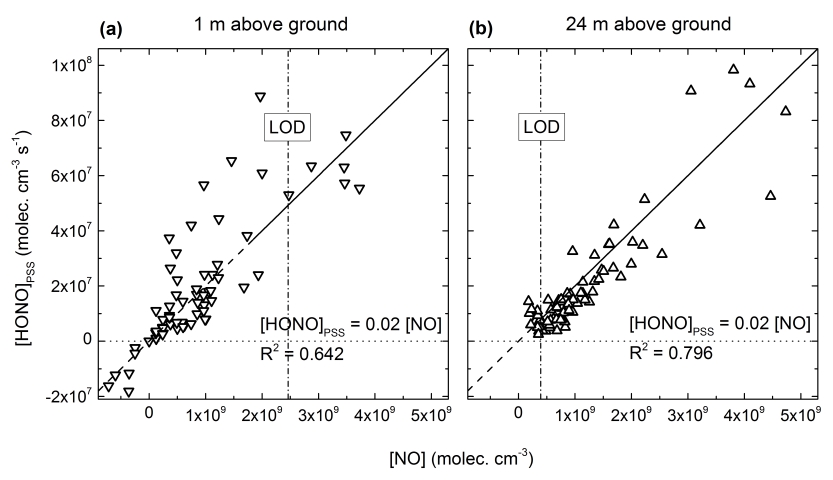

Figure 4. The PSS concentration of HONO, [HONO $]_{P S S}$, at $1 \mathrm{~m}$ measurement height (a) and at $24 \mathrm{~m}$ measurement height (b) is plotted against the concentration of $\mathrm{NO}$ at the corresponding heights. The dash-dotted vertical line reflects the lower limit of detection (LOD) for each NO measurement. The linear fit using a fixed slope of 0.02 and no offset leads to a reasonable correlations between $[\mathrm{HONO}]_{\mathrm{PSS}}$ and $[\mathrm{NO}]$ in both cases.

Not only the known sources seem to be small compared to the photolytic loss rate; the other sinks are also negligible. For example, with a deposition velocity for HONO of $2 \mathrm{~cm} \mathrm{~s}^{-1}$ (Harrison et al., 1996; Su et al., 2008a), a mean daytime HONO concentration of $6.6 \times 10^{8}$ molecules $\mathrm{cm}^{-3}$ and a typical boundary layer height at midday of about $1000 \mathrm{~m}$, the deposition rate is $1.3 \times 10^{3}$ molecules $\mathrm{cm}^{-3} \mathrm{~s}^{-1}$, i.e. $1.9 \mathrm{ppth}^{-1}$, and thus 1 to 2 orders of magnitude less than the photolytic loss. The very low contribution of the dry deposition to HONO loss has already been reported for other measurement campaigns (Su et al., 2008b; Sörgel et al., 2011a).

Horizontal transport $\left(T_{\mathrm{h}}\right)$ can strongly influence budget calculations in urban regions (Lee et al., 2013). However, Hyytiälä is surrounded by a uniform boreal forest with up to $95 \%$ of the area within a $5 \mathrm{~km}$ radius being forested, with mostly Scots pine and spruce (Williams et al., 2011) creating a homogenous fetch. Furthermore, with an average $J(\mathrm{HONO})$ of about $6.7 \times 10^{-4} \mathrm{~s}^{-1}$, corresponding to a HONO lifetime of about $25 \mathrm{~min}$ and an average horizontal wind speed of $2 \mathrm{~m} \mathrm{~s}^{-1}$ (maximum $7 \mathrm{~m} \mathrm{~s}^{-1}$ ), direct emissions of HONO will be transported about $3 \mathrm{~km}$ (maximum $10 \mathrm{~km}$ ) within one lifetime. As most of the surrounding area is covered by forest and the next city, Tampere, is nearly $50 \mathrm{~km}$ away, there are no significant emission sources within the fetch, and thus horizontal advection of direct emissions will have little influence on the HONO concentration during the day. Therefore, the measurement site of SMEAR II, with its homogeneous fetch, is well suited to analyse the behaviour of $P_{\text {unknown }}$ because all processes disturbing the analysis, such as horizontal transport and direct emissions, can be neglected.

The contribution of vertical transport $\left(T_{\mathrm{v}}\right)$ to surface loss of HONO was estimated to be about 50 to $60 \%$ (Wong et al.,

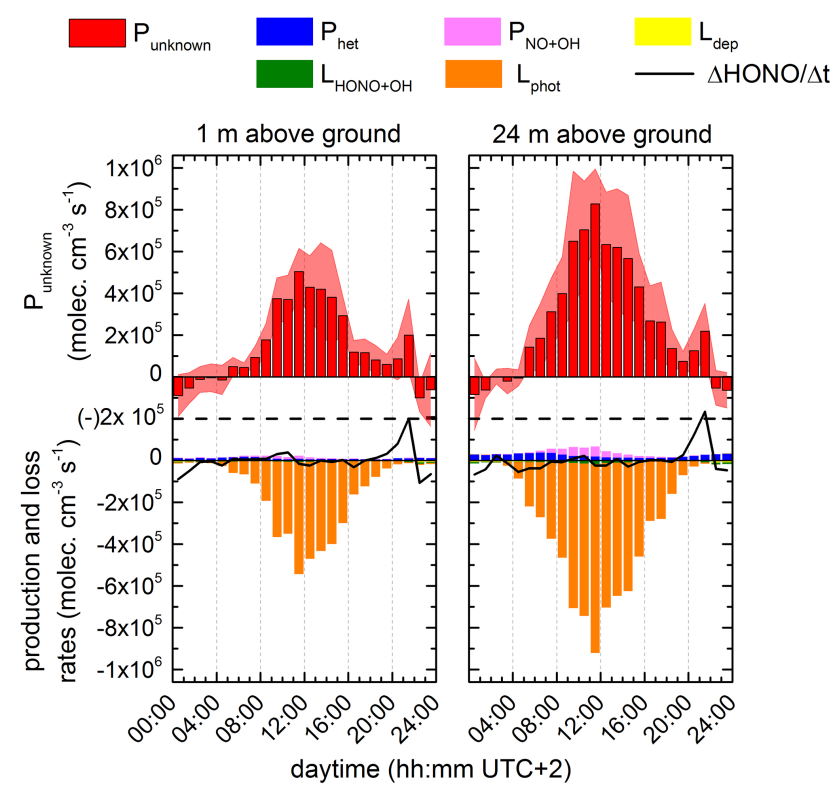

Figure 5. The diel variation of $P_{\text {unknown }}$ (red bars, upper panel) with standard deviation (red shade), the single production and loss terms (coloured bars, lower panel) and the change in HONO concentration $(\Delta \mathrm{HONO} / \Delta \mathrm{t})$ (black line, lower panel) for the two heights are shown.

2013), thus being the dominant loss process for HONO close to the ground. Vertical mixing acts as a sink close to the surface and as an additional, yet unaccounted, source term at elevated levels. Thus, depending on the concentration gradient of HONO and the ratio of photolysis, vertical transport can lead to reciprocal changes in $P_{\text {unknown }}$ above the canopy and below the canopy when using the budget approach. Assuming the unknown source is solely a ground source, $P_{\text {unknown }}$ is represented by $T_{\mathrm{v}}$ at elevated levels $\left(P_{\text {unknown }}=T_{\mathrm{v}}\right)$. Nevertheless, without direct measurements of fluxes or the use of a chemistry transport model, it is difficult to quantify $T_{\mathrm{v}}$ and its contribution remains uncertain. Without explicitly considering $T_{\mathrm{v}}$, the budget approach is only reasonable for wellmixed conditions $\left(T_{\mathrm{v}}=0\right)$.

\subsection{Tracing the missing source}

\subsubsection{Influence of $J\left(\mathrm{NO}_{2}\right)$ on $P_{\text {unknown }}$}

Reactions (R5 and R6-8) comprise several mechanisms of HONO formation from photolytic dissociation of orthonitrophenols or light-induced conversion of $\mathrm{NO}_{2}$ on different reductive surfaces, which are thought to be possible major sources for HONO during daytime (Stemmler et al., 2006). The wavelength range for the proposed reactions is mostly covered and well described by $J\left(\mathrm{NO}_{2}\right)$. Therefore, a source corresponding to these reactions should correlate to $J\left(\mathrm{NO}_{2}\right)$, and especially the light-induced conversion of $\mathrm{NO}_{2}$ should 


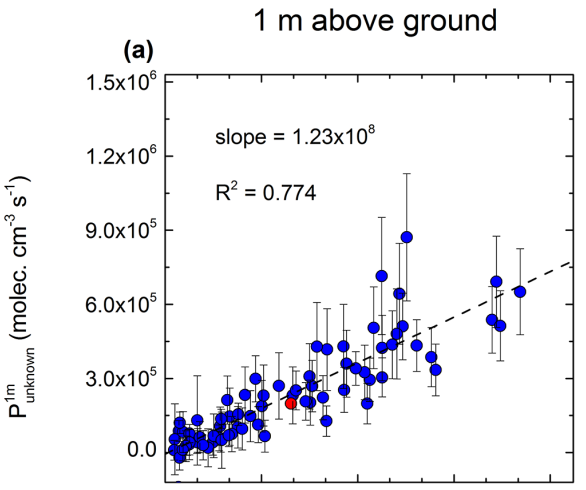

(b)

$24 \mathrm{~m}$ above ground

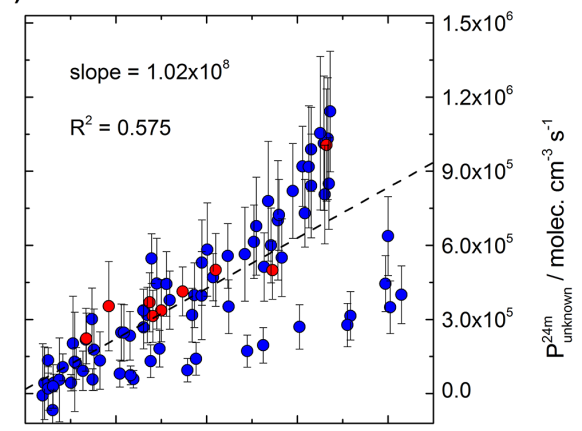

(d)

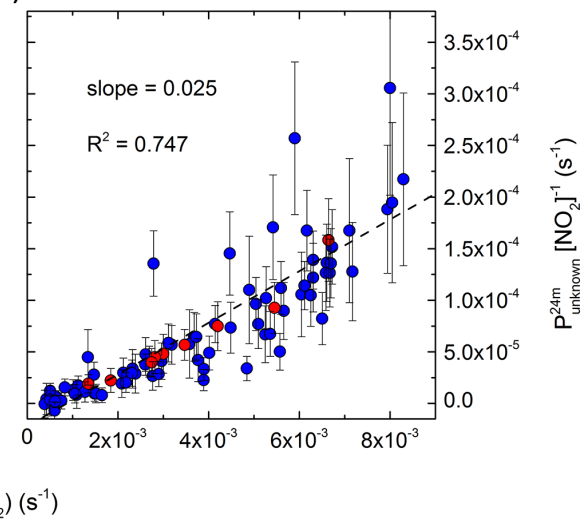

Figure 6. In the upper panels, (a) and (b), $P_{\text {unknown }}$ for both measurement heights is linearly correlated with corresponding $J\left(\mathrm{NO}_{2}\right)$. In the lower panels, (c) and (d), $P_{\text {unknown }}$ is scaled by the $\mathrm{NO}_{2}$ concentration and still linearly correlated with $J\left(\mathrm{NO}_{2}\right)$. Blue dots denote budget data availability at both heights, whereas red dots are available only at the respective measurement height. Linear fits refer to total data available (blue and red).

correlate even better with $P_{\text {unknown }}$ scaled to the $\mathrm{NO}_{2}$ concentration (Fig. 6) (Sörgel et al., 2011a).

Scaling $P_{\text {unknown }}$ with the concentration of $\mathrm{NO}_{2}$ on the ground leads to higher scattering of data points, which might be caused by the higher noise levels of $\mathrm{NO}_{2}$ data on the ground. On the contrary, the correlation above the canopy is improved with similar scaling (Fig. 6b and d). The data points most affected belong to a period of rather cold and very clean conditions with low $\mathrm{NO}_{2}$ concentration of 1.6 to $2.9 \times 10^{9}$ molecules $\mathrm{cm}^{-3}$ (65-118 ppt) on 23 July (Williams et al., 2011). Scaling Punknown above the canopy with corresponding $\mathrm{NO}_{2}$ concentration increases the correlation with $J\left(\mathrm{NO}_{2}\right)$. This leads to the assumptions that either $\mathrm{NO}_{2}$ plays a direct role in $\mathrm{HONO}$ formation or that in general $\mathrm{NO}_{2}$ is a tracer for reactive nitrogen (other potential HONO precursors) in the atmosphere. The correlation between $P_{\text {unknown }}$ and $J\left(\mathrm{NO}_{2}\right)$ below the canopy descends by scaling $P_{\text {unknown }}$ with $\mathrm{NO}_{2}$ concentrations due to data scattering as mentioned above, HONO deposition on the forest floor (Sörgel et al., 2014) or different pathways of $\mathrm{HONO}$ and $\mathrm{NO}_{2}$ formation below the canopy. $\mathrm{NO}_{2}$ below the canopy is formed by shifted PSS and additional NO soil emissions oxidised by $\mathrm{O}_{3}$ (Rummel et al., 2002). Opposed due to low OH and NO val- ues below the canopy, the shift in the $[\mathrm{HONO}]_{\text {PSS }}$ by reduced radiation below the canopy has minor influence on $\mathrm{HONO}$ values (Fig. 3).

Since measurements of ortho-nitrophenols were not available, it is not possible to rule out photolytic conversion of these compounds as a possible pathway. However, from Eq. (3) we estimate that the concentration of o-NPs has to exceed the concentration of HONO by a factor of about 70 in order to compensate for the photolytic loss of HONO. Taking the average daytime mixing ratio of HONO above the canopy, the resulting mixing ratio of o-NPs would be about 1.8 ppb. Based on earlier studies (Bejan et al., 2006; Kourtchev et al., 2013), the concentration in a clean environment such as Hyytiälä should be much lower and, thus, insignificant for HONO formation.

Another possible HONO source that depends on $J\left(\mathrm{NO}_{2}\right)$ is the photolytic activation of organic surface reactants (R68) that reduces $\mathrm{NO}_{2}$ and forms HONO (Stemmler et al., 2006). However, as previously mentioned, due to the lack of in situ measurements of all quantities, this contribution could not be calculated. Obviously, it is likely that humic acids or similar compounds occur in the highly organic surroundings of the boreal forest. A strong hint of such a source might 
be the merging effect on the correlation of the $P_{\text {unknown with }}$ $J\left(\mathrm{NO}_{2}\right)$ by scaling with the concentration of $\mathrm{NO}_{2}$ above the canopy.

As radical formation is driven by sunlight as well, the recently proposed reaction of the $\mathrm{HO}_{2}$-water complex with $\mathrm{NO}_{2}$ as a potential HONO source (Li et al., 2014) might be correlated to radiation as well. The contribution of this source was estimated using the measured $\mathrm{HO}_{2}$ concentration, a water vapour mixing ratio of $1.5 \%$ (Hens et al., 2014) and the equilibrium constant (Sander et al., 2011), to calculate the complex formation. All calculations were made using 298 $\mathrm{K}$ and $1013 \mathrm{hPa}$ as standard conditions. Hence about $20 \%$ of the $\mathrm{HO}_{2}$ is complexed to water. The related $\mathrm{HONO}$ formation was calculated by using the rate constant $(298 \mathrm{~K}, 1013 \mathrm{hPa})$ of the reaction of $\mathrm{HO}_{2}$ and $\mathrm{NO}_{2}$ without water according to Atkinson et al. (2004) and a $20 \%$ enhancement of the reaction rate due to water vapour for conditions in the lower atmosphere (Sander and Peterson, 1984). Assuming a $100 \%$ yield of HONO formation from the reaction of the complexed $\mathrm{HO}_{2}$ with $\mathrm{NO}_{2}$, as postulated by Li et al. (2014), the HONO formation by this source is a factor of 3 to 10 higher than the required unknown source. $\mathrm{Li}$ et al (2014) reproduced their unknown HONO source by including these reactions. However, their required HONO source was about a factor of 4 higher $\left(\sim 600 \mathrm{ppt} \mathrm{h}^{-1}\right)$ than in our case at comparable $\mathrm{NO}_{2}$ (0.5-1 ppb) and $\mathrm{HO}_{2}\left(5-10 \times 10^{8}\right.$ molec $\left.\mathrm{cm}^{-3}\right)$ levels. Additionally, the HONO to $\mathrm{NO}_{\mathrm{x}}$ ratios were normally below $10 \%$ in our study, while they were relatively high $(\sim 10-30 \%)$ in the study of Li et al. (2014). Consequently, our results indicate a $\mathrm{NO}_{\mathrm{x}}$ to $\mathrm{HONO}$ conversion that is smaller than in $\mathrm{Li}$ et al. (2014). Using the upper limit rate constant for HONO formation in the reaction of $\mathrm{NO}_{2}$ and $\mathrm{HO}_{2}$ without water given by Tyndall et al. (1995), this reaction did not lead to substantial HONO formation (factor of 100 to 200 below the required values), which is consistent with earlier findings (Kleffmann, 2007). Hence the contribution of this source to HONO formation in our study will depend on the reaction mechanism (i.e. the yield of HONO), which is still unclear and needs to be further investigated in laboratory studies.

\subsubsection{Indirect influence of $J\left(\mathrm{NO}_{2}\right)$ on $P_{\text {unknown }}$}

Besides the activation or the photolytic reaction of molecules by $J\left(\mathrm{NO}_{2}\right)$, the radiation also influences other parameters. One of these is the temperature of soil. The temperature of the soil surface changes faster and with more force than in deeper layers of soil and is driven by radiative heating and cooling. Nitrification and denitrification by microorganisms takes place at the uppermost layer of soil and produces reactive nitrogen gases (Conrad, 1996). The rate of reactive nitrogen formation depends on many parameters like soil water content (SWC), $\mathrm{pH}$, nutrient availability and, important in this context, the temperature of soil (Skopp et al., 1990; Oswald et al., 2013). Therefore, radiation can accelerate the formation of HONO by soil.
Since we did not measure the potential emission of HONO by soil in the field, a soil sample was taken afterwards and measured in the laboratory under controlled conditions according to Oswald et al. (2013). Concentrations of nutrients were quite low with ammonium being $(1.60 \pm 0.56) \mathrm{mg} \mathrm{kg}^{-1} \mathrm{~N}-\mathrm{NH}_{4}^{+}$, while $\mathrm{NO}_{3}^{-}$and $\mathrm{NO}_{2}^{-}$were not measurable (below LOD, i.e. $2 \mathrm{mg} \mathrm{kg}^{-1} \mathrm{~N}_{-} \mathrm{NO}_{3}^{-}$and $0.07 \mathrm{mg} \mathrm{kg}^{-1} \mathrm{~N}^{-\mathrm{NO}_{2}^{-}}$). This is in good agreement with Korhonen et al. (2013), who found that the measurement site of Hyytiälä provides nutrient poor soils with $\mathrm{NH}_{4}^{+}$as the dominant inorganic nitrogen compound in the extract of soil organic layer $\left(0.31 \mathrm{~kg} \mathrm{ha}^{-1} \mathrm{~N}-\mathrm{NH}_{4}^{+}\right)$and the first $30 \mathrm{~cm}$ of mineral soil, while $\mathrm{NO}_{3}^{-}$forms only $0.6 \%$ of it. The soil $\mathrm{pH}$ was very low with a value of about 3.0. The measurement of the soil sample showed no significant emission fluxes of HONO being below the limit of detection $(0.08$ $\mathrm{ng} \mathrm{m}^{-2} \mathrm{~s}^{-1}=0.288 \mu \mathrm{g} \mathrm{m}^{-2} \mathrm{~h}^{-1}$ ) and emission fluxes of NO scattering around the limit of detection $\left(1 \mathrm{ng} \mathrm{m}^{-2} \mathrm{~s}^{-1}=\right.$ $\left.3.6 \mu \mathrm{g} \mathrm{m}^{-2} \mathrm{~h}^{-1}\right)$. This is in good agreement with Oswald et al. (2013) and Maljanen et al. (2013), who both found that acidic forest soils tend to low emission fluxes of HONO. Maljanen et al. (2013) measured a maximum HONO flux of about $2 \mu \mathrm{g} \mathrm{m}^{-2} \mathrm{~h}^{-1}$ in terms of $\mathrm{N}$. This would equal a source strength of $7.1 \times 10^{3}$ molecules $\mathrm{cm}^{-3} \mathrm{~s}^{-1}\left(1 \mathrm{ppth}^{-1}\right)$ considering a boundary layer height of $1000 \mathrm{~m}$ and hence is negligible. The laboratory measurements of soil samples represent potential HONO emission fluxes as HONO can simultaneously be taken up by soil (Donaldson et al., 2014) or deposited to soil and re-emitted as proposed by VandenBoer et al. (2013). In addition to emissions from the soil surface, the evaporation of dew can release HONO (He et al., 2006), also enhancing HONO fluxes in the early morning when temperatures increase.

\subsubsection{HONO formation by nitric acid photolysis}

Adsorbed $\mathrm{HNO}_{3}$ on humid surfaces (R9) seems to be more rapidly photolysed than $\mathrm{HNO}_{3}$ in the gas phase or in an aqueous solution (Zhou et al., 2003; Abida et al., 2012). Therefore, leaves and needles loaded with nitric acid could be a major source of HONO in clean environments (Zhou et al., 2011). This mechanism has also been postulated as significant for the boreal forest by Raivonen et al. (2006) to explain light-induced $\mathrm{NO}_{y}\left(\mathrm{NO}, \mathrm{NO}_{2}, \mathrm{HONO}, \mathrm{HNO}_{3}\right.$, peroxy acyl nitrate) emissions. To estimate the strength of this source we used a constant surface loading of $\mathrm{HNO}_{3}$ of $(8.3 \pm 3.1) \times 10^{-5} \mathrm{~mol} \mathrm{~m}^{-2}$, which is close to one monolayer coverage (Zhou et al., 2011). The site investigated by Zhou et al. (2011) (PROPHET) was located in a mixed forest $\left(\sim 45^{\circ} \mathrm{N}\right)$, whereas the SMEAR II station is located in a boreal forest $\left(\sim 62^{\circ} \mathrm{N}\right)$ with scots pine as the main tree species. Nevertheless, both sites are rural forested sites with low local pollution and low $\mathrm{NO}_{\mathrm{x}}$ concentrations (Kulmala et al., 2000; Carroll et al., 2001). Therefore, we assume that the values derived by Zhou et al. (Zhou et al., 2011; Zhou et al., 2003) con- 


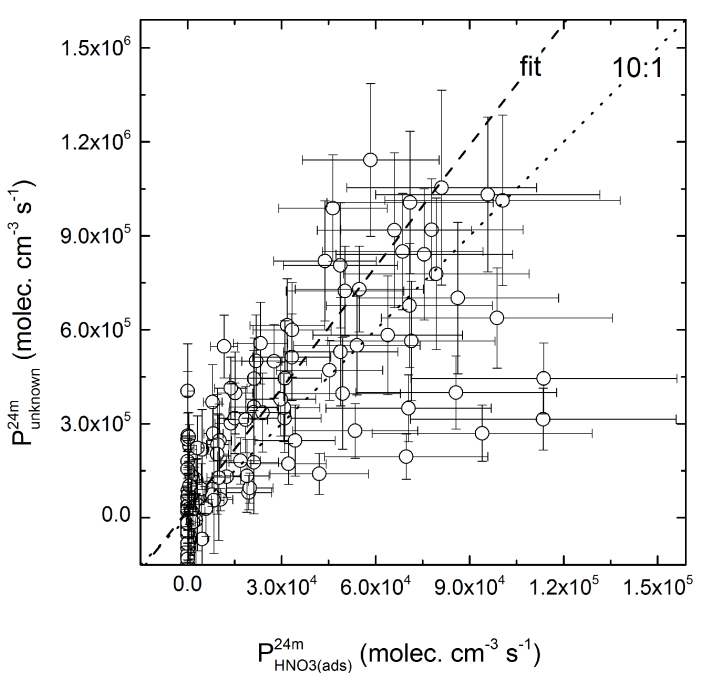

Figure 7. $P_{\text {unknown }}$ at the measurement height of $24 \mathrm{~m}$ during daytime is plotted against the production of HONO from photolysis of adsorbed $\mathrm{HNO}_{3}$ on leaf surfaces, $P_{\mathrm{HNO}_{3} \text { (ads) }}$. With an enhancement factor of 43 and a surface loading of $(8.3 \pm 3.1) \times 10^{-5}$ mol m$~^{-2}$, it might explain up to $10 \%$ of $P_{\text {unknown, indicated by }}$ the 10 to 1 line (dotted line). The York linear fit (York et al., $2004)$ yields in $P_{\text {unknown }}=(12.9 \pm 1.0) \times P_{\mathrm{HNO}_{3(\mathrm{ads})}}+(2.4 \pm 1.1) \times$ $10^{4}$ molecules $\mathrm{cm}^{-3} \mathrm{~s}^{-1}$.

stitute a reasonable estimate for the conditions at the SMEAR site. The gas phase photolysis frequency for $\mathrm{HNO}_{3}$ was parameterized using $J\left(\mathrm{NO}_{2}\right)$ and $J\left(\mathrm{O}^{1} \mathrm{D}\right)$ (Sander et al., 2011). By adsorbing to the surface, the absorption cross sections of $\mathrm{HNO}_{3}$ increases (Zhu et al., 2010; Abida et al., 2012), which is typically deduced by the use of an empirical enhancement factor for natural systems (Zhou et al., 2011; Li et al., 2012). We used the enhancement factor of 43 for Fig. 7 according to a similar environment in the study of Zhou et al. (Zhou et al., 2003; Zhou et al., 2011).

To explain $P_{\text {unknown }}$ of HONO (Fig. 7), the photolysis rate of surface-adsorbed $\mathrm{HNO}_{3}$ needs to be enhanced more than 400 times compared to the photolysis in the gas phase, which is still within the estimated range (e.g. Zhu et al., 2008; Zhu et al., 2010; Baergen and Donaldson, 2013). Nevertheless, the enhancement factor given by Zhou et al. (2011) is the only reported value on the HONO formation rate (instead of $\mathrm{HNO}_{3}$ photolysis rate) with respect to $\mathrm{HNO}_{3}$ photolysis on natural surfaces. The error of $P_{\mathrm{HNO}_{3}(\text { ads) }}$ was calculated using the standard error of the surface loading of $\mathrm{HNO}_{3}$ (Zhou et al., 2011). $J\left(\mathrm{HNO}_{3}\right)$ constitutes the only variable of $P_{\mathrm{HNO}_{3} \text { (ads) }}$ and is closely correlated to $J\left(\mathrm{NO}_{2}\right)$ and $\mathrm{J}\left(\mathrm{O}^{1} \mathrm{D}\right)$. This leads to a similar correlation of $P_{\text {unknown }}$ with $P_{\left.\mathrm{HNO}_{3(\text { ads }}\right)}$, as previously seen with $J\left(\mathrm{NO}_{2}\right)$ (Fig. 6). An additional correlation might derive from the mechanism of $\mathrm{HNO}_{3}$ photolysis, which is not fully understood at this time. Zhou et al. (2011) proposed that $\mathrm{NO}_{2}$ formed during $\mathrm{HNO}_{3}$ photolysis reacts further with organics on the surface to form HONO: (R(6)$\mathrm{R}(8)$ ) as proposed by Stemmler et al. (2006).

\subsection{Direct comparison of $\boldsymbol{P}_{\text {unknown }}$ determined for two different heights}

The ratio of $J\left(\mathrm{NO}_{2}\right)$ at $24 \mathrm{~m}$ to $J\left(\mathrm{NO}_{2}\right)$ at $2 \mathrm{~m}$ tracks the ratio of direct and diffuse radiation penetrating the canopy. In the early morning, the ratio increases due to increasing direct sunlight at the upper height. With the rising sun more direct sunlight penetrates the canopy and a rather constant ratio develops, which seems to be influenced by light patches. The ratio of $P_{\text {unknown }}$ at $24 \mathrm{~m}$ to $P_{\text {unknown }}$ at $1 \mathrm{~m}$ during daytime is mainly above 1 except for the first value, where $P_{\text {unknown }}$ at both heights was still negative (Fig. 5). It strongly decreases from values above 4 in the morning hours before stabilising with values around 2; however, values still decrease until $2 \mathrm{~h}$ after reaching the minimum of solar zenith angle $\left(\sim 43^{\circ}\right)$. This diel pattern can be explained by a combination of two processes: the change of the photolysis frequency and the change of the concentration gradient (Fig. 8a). The product of both the concentration and the photolysis frequency equals the photolytic loss rate, $L_{\text {phot }}$, which is the unbalanced sink that determines $P_{\text {unknown }}$ (see Figs. 5, 8b and c). This is at least valid from 08:30 to 17:30, when the contribution of other source and sink terms is less than $20 \%$. The HONO concentrations above the canopy are higher than below the canopy in the morning (values over unity in Fig 8a). The gradients vary around zero from late morning to noon, and in the afternoon the concentrations below the canopy are higher. This closely resembles the pattern found by Sörgel et al. (2011b) for a different forest ecosystem and thus might be typical for forests in general. Sörgel et al. (2011b) showed that this could be attributed to different sources and sinks and the extent of the vertical exchange between the forest and the atmosphere above. However, the variability of the ratios is smallest at minimum solar zenith angle, which is the maximum of $J(\mathrm{HONO})$. In a strict sense, this is the only period where the budget could be used for the determination of $P_{\text {unknown }}$ because the assumptions, such as well-mixed conditions (i.e. no concentration gradients), stationarity due to low lifetime of HONO and potential establishment of a PSS, are fulfilled. During this period it could be questioned if a budget below the canopy makes sense; the portion below the canopy, where $J(\mathrm{HONO})$ and thus $L_{\text {phot }}$ are reduced, is very small compared to the whole boundary layer, and recombination of $\mathrm{NO}$ and $\mathrm{OH}$ below canopy has been found to play a minor role (Sect. 3.2).

Impressively, $P_{\text {unknown }}$ correlates much better with $L_{\text {phot }}$ (Fig. 8b and c) than with $J\left(\mathrm{NO}_{2}\right)$ or the ratio of $J\left(\mathrm{NO}_{2}\right)$ to the concentration of $\mathrm{NO}_{2}$ (Fig. 6). This correlation (Fig. 8b and c) is not disturbed by any environmental condition such as the different regimes of stressed and normal boreal; even more astonishing, it is not disturbed by the wild-fire pollution plumes transported from Russia (Nölscher et al., 2012). The 

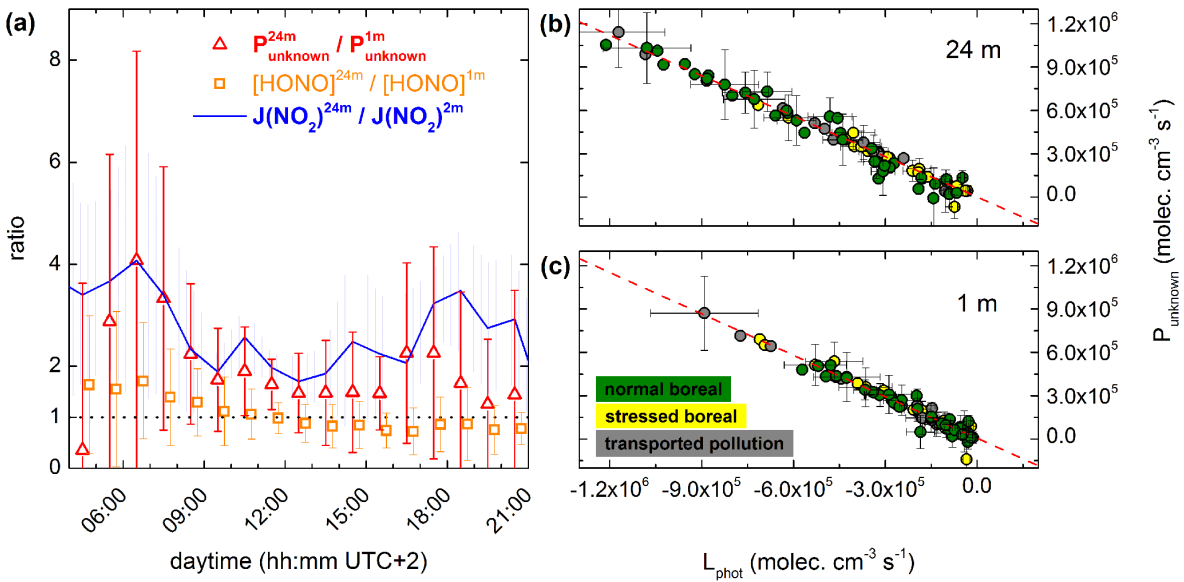

Figure 8. (a) The average ratio of $P_{\text {unknown }}^{24 \mathrm{~m}}$ to $P_{\text {unknown }}^{1 \mathrm{~m}}$ (red triangles), the average ratio of $[\mathrm{HONO}]^{24 \mathrm{~m}}$ to $[\mathrm{HONO}]^{1 \mathrm{~m}}$ (orange squares) and the average ratio of $J\left(\mathrm{NO}_{2}\right)^{24 \mathrm{~m}}$ to $J\left(\mathrm{NO}_{2}\right)^{2 \mathrm{~m}}$ (blue line) change during daytime (lifetime of $\mathrm{HONO}<4 \mathrm{~h}$ ). For clarity, a second xcoordinate for the ratio of $[\mathrm{HONO}]^{24 \mathrm{~m}}$ to $[\mathrm{HONO}]^{1 \mathrm{~m}}$ is used with a shift of $+15 \mathrm{~min}$ but is not shown. (b) $P_{\text {unknown }}^{24 \mathrm{~m}}$ and (c) $P_{\text {unkno }}^{1 \mathrm{~m}}$ are plotted against the photolytic loss rate of HONO at $24 \mathrm{~m}$ and $1 \mathrm{~m}$ above ground respectively. The York linear fit (York et al., 2004) of $P_{\text {unknown }}^{24 \mathrm{~m}}$ with $L_{\text {phot }}^{24 \mathrm{~m}}$ and $P_{\text {unknown }}^{1 \mathrm{~m}}$ with $L_{\text {phot }}^{1 \mathrm{~m}}$ yields in $P_{\text {unknown }}^{24 \mathrm{~m}}=-(0.93 \pm 0.05) \times L_{\text {phot }}^{24 \mathrm{~m}}+(0.9 \pm 14.2) \times 10^{3}$ molecules cm $\mathrm{c} \mathrm{s}^{-1}$ and $P_{\text {unknown }}^{1 \mathrm{~m}}=-(0.96 \pm 0.08) \times L_{\text {phot }}^{1 \mathrm{~m}}+(0.6 \pm 11.9) \times 10^{3}$ molecules $\mathrm{cm}^{-3} \mathrm{~s}^{-1}$ respectively.

almost perfect correlation of $P_{\text {unknown }}$ with $L_{\text {phot }}$ is caused by the low contribution to the budget of all other processes (sources and sinks) considered so far. Even including the parameterized $\mathrm{HNO}_{3}$ photolysis (Sect. 3.4.3) would not change much because it is only around $10 \%$ of $P_{\text {unknown. There- }}$ fore, the unknown source is a process that exactly balances HONO photolysis or the sink itself is erroneous. Nevertheless, this unbalanced photolysis term $\left(P_{\text {unknown }}\right)$ has been found by applying different techniques for HONO detection, such as LOPAP (e.g. Kleffmann et al., 2005; Sörgel et al., 2011a), denuder (Acker et al., 2006), differential optical absorption spectroscopy (Alicke et al., 2002; Wong et al., 2012) and recently by using chemical ionisation mass spectroscopy (VandenBoer et al., 2013). Consequently, the unknown HONO source is very unlikely to be caused by an instrument's artefact. Additionally, recent flux measurements reported strong daytime upward fluxes of HONO (Zhou et al., 2011, Ren et al., 2011), thus confirming a ground source of HONO.

\section{Conclusions}

Concentrations of HONO during daytime exceeded the expected values calculated by the PSS on average by a factor of about 20 and thus led to an imbalanced budget above and below the canopy. An additional yet unknown source is required to balance the budget. However, photolysis of orthonitrophenols is likely of minor importance under the clean environment of the boreal forest. A laboratory measurement of a soil sample in a dynamic chamber shows that direct soil emissions of HONO are insignificant for the measurement site in the boreal forest, featuring low soil nutrient content and low soil $\mathrm{pH}$. However, the photolytically active radiation has a major influence on the budget of HONO, since the missing source resembles the photolytic daytime loss of HONO. It was not possible to clearly identify the most important source term, but a tendency for a possible coupling of different processes is most likely. For instance, the photolytic dissociation of $\mathrm{HNO}_{3}$ adsorbed on humid surfaces and the conversion of $\mathrm{NO}_{2}$ on photolytically activated surfaces, like humic acids, might occur simultaneously. However, the almost perfect correlation of $P_{\text {unknown }}$ with $L_{\text {phot }}$ is caused by the low contribution of the considered processes to the budget and hence the unknown source is a process that exactly balances HONO photolysis. Further field investigations are needed to understand daytime HONO chemistry and its implication for the budget. Especially the role of vertical mixing needs to be analysed in more detail.

Acknowledgements. This project was funded by the Max Planck Society. The work was supported by the Max Planck Graduate Centre and the Johannes Gutenberg University of Mainz. The entire HUMPPA-COPEC team is grateful for the support of the Hyytiälä site engineers and staff. We would like to thank the European Community Research Infrastructure Action under the FP6 "Structuring the European Research Area" Programme (EUSAAR 15 contract no. RII3-CT-2006-026140) for the support. The campaign measurements and analyses were supported by the ERC Grant ATMNUCLE (project no. 227463), Academy of Finland Centre of Excellence program (project no. 1118615), the European integrated project on aerosol cloud climate and air quality interactions EUCAARI (project no. 036833-2), the EUSAAR TNA (project no. 400586) and the IMECC TA (project no. 4006261). 
We also wish to thank C. Breitenberger, J. Crowley, T. Klüpfel, U. Parchatka, M. Rudolf and L. Ganzeveld for their support during HUMPPA-COPEC 2010. We are furthermore grateful to S. Hohlmann, M. Welling, D. Plake, A. Moravek, E. Falge, T. Behrendt and D. Mogensen for supporting the measurements and for the fruitful discussions.

The service charges for this open access publication have been covered by the Max Planck Society.

Edited by: J. Liggio

\section{References}

Abida, O., Du, J., and Zhu, L.: Investigation of the photolysis of the surface-adsorbed $\mathrm{HNO}_{3}$ by combining laser photolysis with Brewster angle cavity ring-down spectroscopy, Chem. Phys. Lett., 534, 77-82, doi:10.1016/j.cplett.2012.03.034, 2012.

Acker, K., Möller, D., Wieprecht, W., Meixner, F. X., Bohn, B., Gilge, S., Plass-Dülmer, C., and Berresheim, H.: Strong daytime production of $\mathrm{OH}$ from $\mathrm{HNO}_{2}$ at a rural mountain site, Geophys. Res. Lett., 33, L02809, doi:10.1029/2005GL024643, 2006.

Alicke, B., Platt, U., and Stutz, J.: Impact of nitrous acid photolysis on the total hydroxyl radical budget during the limitation of oxidant production/Pianura Padana Produzione di Ozono study in Milan, J. Geophys. Res., 107, LOP9-1-LOP9-LOP9-17, doi:10.1029/2000jd000075, 2002.

Atkinson, R., Baulch, D. L., Cox, R. A., Crowley, J. N., Hampson, R. F., Hynes, R. G., Jenkin, M. E., Rossi, M. J., and Troe, J.: Evaluated kinetic and photochemical data for atmospheric chemistry: Volume $\mathrm{I}$ - gas phase reactions of $\mathrm{O}_{\mathrm{x}}, \mathrm{HO}_{\mathrm{x}}, \mathrm{NO}_{\mathrm{x}}$ and $\mathrm{SO}_{\mathrm{x}}$ species, Atmos. Chem. Phys., 4, 1461-1738, doi:10.5194/acp-41461-2004, 2004.

Aubin, D. G. and Abbatt, J. P. D.: Interaction of $\mathrm{NO}_{2}$ with hydrocarbon soot: focus on HONO yield, surface modification, and mechanism, J. Phys. Chem. A, 111, 6263-6273, 2007.

Baergen, A. M. and Donaldson, D. J.: Photochemical renoxification of nitric acid on real urban grime, Environ. Sci. Technol., 47, 815-820, doi:10.1021/es3037862, 2013.

Bejan, I., Abd El Aal, Y., Barnes, I., Benter, T., Bohn, B., Wiesen, P., and Kleffmann, J.: The photolysis of ortho-nitrophenols: a new gas phase source of HONO, Phys. Chem. Chem. Phys., 8, 20282035, 2006.

Bohn, B., Corlett, G. K., Gillmann, M., Sanghavi, S., Stange, G., Tensing, E., Vrekoussis, M., Bloss, W. J., Clapp, L. J., Kortner, M., Dorn, H.-P., Monks, P. S., Platt, U., PlassDülmer, C., Mihalopoulos, N., Heard, D. E., Clemitshaw, K. C., Meixner, F. X., Prevot, A. S. H., and Schmitt, R.: Photolysis frequency measurement techniques: results of a comparison within the ACCENT project, Atmos. Chem. Phys., 8, 53735391, doi:10.5194/acp-8-5373-2008, 2008.

Carroll, M. A., Bertman, S. B., and Shepson, P. B.: Overview of the Program for Research on Oxidants: PHotochemistry, Emissions, and Transport (PROPHET) summer 1998 measurements intensive, J. Geophys. Res., 106, 24 275-24 288, 2001.
Conrad, R.: Soil microorganisms as controllers of atmospheric trace gases $\left(\mathrm{H}_{2}, \mathrm{CO}, \mathrm{CH}_{4}, \mathrm{OCS}, \mathrm{N}_{2} \mathrm{O}\right.$, and $\left.\mathrm{NO}\right)$, Microbiol. Rev., 60, 609-640, 1996.

De Jesus Medeiros, D. and Pimentel, A. S.: New insights in the atmospheric $\mathrm{HONO}$ formation: new pathways for $\mathrm{N}_{2} \mathrm{O}_{4}$ isomerization and $\mathrm{NO}_{2}$ dimerization in the presence of water, J. Phys. Chem. A, 115, 6357-6365, 2011.

Donaldson, M. A., Berke, A. E., and Raff, J. D.: Uptake of Gas Phase Nitrous Acid onto Boundary Layer Soil Surfaces, Environ. Sci. Technol., 48, 375-383, doi:10.1021/es404156a, 2014.

Elshorbany, Y. F., Steil, B., Brühl, C., and Lelieveld, J.: Impact of HONO on global atmospheric chemistry calculated with an empirical parameterization in the EMAC model, Atmos. Chem. Phys., 12, 9977-10000, doi:10.5194/acp-12-9977-2012, 2012.

Finlayson-Pitts, B. J., Wingen, L. M., Sumner, A. L., Syomin, D., and Ramazan, K. A.: The heterogeneous hydrolysis of $\mathrm{NO}_{2}$ in laboratory systems and in outdoor and indoor atmospheres: an integrated mechanism, Phys. Chem. Chem. Phys., 5, 223-242, doi:10.1039/b208564j, 2003.

Goodman, A. L., Bernard, E. T., and Grassian, V. H.: Spectroscopic study of nitric acid and water adsorption on oxide particles: enhanced nitric acid uptake kinetics in the presence of adsorbed water, J. Phys. Chem. A, 105, 6443-6457, doi:10.1021/jp0037221, 2001.

Harrison, R. M., Peak, J. D., and Collins, G. M.: Tropospheric cycle of nitrous acid, J. Geophys. Res.-Atmos., 101, 14429-14439, 1996.

He, Y., Zhou, X., Hou, J., Gao, H., and Bertman, S. B.: Importance of dew in controlling the air-surface exchange of HONO in rural forested environments, Geophysical Research Letters, 33, L02813, 10.1029/2005GL024348, 2006.

Heland, J., Kleffmann, J., Kurtenbach, R., and Wiesen, P.: A new instrument to measure gaseous nitrous acid (HONO) in the atmosphere, Environ. Sci. Technol., 35, 3207-3212, doi:10.1021/es000303t, 2001.

Hens, K., Novelli, A., Martinez, M., Auld, J., Axinte, R., Bohn, B., Fischer, H., Keronen, P., Kubistin, D., Nölscher, A. C., Oswald, R., Paasonen, P., Petäjä, T., Regelin, E., Sander, R., Sinha, V., Sipilä, M., Taraborrelli, D., Tatum Ernest, C., Williams, J., Lelieveld, J., and Harder, H.: Observation and modelling of $\mathrm{HO}_{\mathrm{x}}$ radicals in a boreal forest, Atmos. Chem. Phys., 14, 8723-8747, doi:10.5194/acp-14-8723-2014, 2014.

Hosaynali Beygi, Z., Fischer, H., Harder, H. D., Martinez, M., Sander, R., Williams, J., Brookes, D. M., Monks, P. S., and Lelieveld, J.: Oxidation photochemistry in the Southern Atlantic boundary layer: unexpected deviations of photochemical steady state, Atmos. Chem. Phys., 11, 8497-8513, doi:10.5194/acp-118497-2011, 2011.

Junninen, H., Lauri, A., Keronen, P., Aalto, P., Hiltunen, V., Hari, P., and Kulmala, M.: Smart-SMEAR: on-line data exploration and visualization tool for SMEAR stations., Boreal Environ. Res., 14, 447-457, 2009.

Kleffmann, J.: Daytime sources of nitrous acid (HONO) in the atmospheric boundary layer, Chem. Phys. Chem., 8, 1137-1144, 2007.

Kleffmann, J., Heland, J., Kurtenbach, R., Lörzer, J., and Wiesen, P.: A new instrument (LOPAP) for the detection of nitrous acid (HONO), Environ. Sci. Pollut. R., 4, 48-54, 2002. 
Kleffmann, J., Kurtenbach, R., Lörzer, J., Wiesen, P., Kalthoff, N., Vogel, B., and Vogel, H.: Measured and simulated vertical profiles of nitrous acid - Part I: Field measurements, Atmos. Environ., 37, 2949-2955, doi:10.1016/s1352-2310(03)00242-5, 2003.

Kleffmann, J., Gavriloaiei, T., Hofzumahaus, A., Holland, F., Koppmann, R., Rupp, L., Schlosser, E., Siese, M., and Wahner, A.: Daytime formation of nitrous acid: a major source of $\mathrm{OH}$ radicals in a forest, Geophys. Res. Lett., 32, L05818 doi:10.1029/2005GL022524, 2005.

Korhonen, J. F. J., Pihlatie, M., Pumpanen, J., Aaltonen, H., Hari, P., Levula, J., Kieloaho, A.-J., Nikinmaa, E., Vesala, T., and Ilvesniemi, H.: Nitrogen balance of a boreal Scots pine forest, Biogeosciences, 10, 1083-1095, doi:10.5194/bg-10-1083-2013, 2013.

Kourtchev, I., Fuller, S., Aalto, J., Ruuskanen, T. M., McLeod, M. W., Maenhaut, W., Jones, R., Kulmala, M., and Kalberer, M.: Molecular composition of boreal forest aerosol from Hyytiala, Finland, using ultrahigh resolution mass spectrometry, Environ. Sci. Technol., 47, 4069-4079, doi:10.1021/es3051636, 2013.

Kraus, A. and Hofzumahaus, A.: Field measurements of atmospheric photolysis frequencies for $\mathrm{O}_{3}, \mathrm{NO}_{2}, \mathrm{HCHO}, \mathrm{CH}_{3} \mathrm{CHO}$, $\mathrm{H}_{2} \mathrm{O}_{2}$, and $\mathrm{HONO}$ by UV spectroradiometry, J. Atmos. Chem., 31, 161-180, 1998.

Kubota, M. and Asami, T.: Volatilization of nitrous-acid from upland soils, Soil Sci. Plant Nutr., 31, 27-34, 1985.

Kulmala, M., Rannik, U., Pirjola, L., Dal Maso, M., Karimäki, J., Asmi, A., Jäppinen, A., Karhu, V., Korhonen, H., Malvikko, S. P., Puustinen, A., Raittila, J., Romakkaniemi, S., Suni, T., YliKoivisto, S., Paatero, J., Hari, P., and Vesala, T.: Characterization of atmospheric trace gas and aerosol concentrations at forest sites in southern and northern Finland using back trajectories, Boreal Environ. Res., 5, 315-336, 2000.

Lammel, G. and Cape, J. N.: Nitrous acid and nitrite in the atmosphere, Chem. Soc. Rev., 25, 361-369, 1996.

Lee, B. H., Wood, E. C., Herndon, S. C., Lefer, B. L., Luke, W. T., Brune, W. H., Nelson, D. D., Zahniser, M. S., and Munger, J. W.: Urban measurements of atmospheric nitrous acid: a caveat on the interpretation of the HONO photostationary state, J. Geophys. Res.-Atmos., 118, 12274-12281, doi:10.1002/2013JD020341, 2013.

Li, X., Brauers, T., Häseler, R., Bohn, B., Fuchs, H., Hofzumahaus, A., Holland, F., Lou, S., Lu, K. D., Rohrer, F., Hu, M., Zeng, L. M., Zhang, Y. H., Garland, R. M., Su, H., Nowak, A., Wiedensohler, A., Takegawa, N., Shao, M., and Wahner, A.: Exploring the atmospheric chemistry of nitrous acid (HONO) at a rural site in Southern China, Atmos. Chem. Phys., 12, 14971513, doi:10.5194/acp-12-1497-2012, 2012.

Maljanen, M., Yli-Pirilä, P., Hytönen, J., Joutsensaari, J., and Martikainen, P. J.: Acidic northern soils as sources of atmospheric nitrous acid (HONO), Soil Biol. Biochem., 67, 94-97, doi:10.1016/j.soilbio.2013.08.013, 2013.

Monge, M. E., D’Anna, B., Mazri, L., Giroir-Fendler, A., Ammann, M., Donaldson, D. J., and George, C.: Light changes the atmospheric reactivity of soot, P. Natl. Acad. Sci. USA, 107, 6605-6609, doi:10.1073/pnas.0908341107, 2010.

Nölscher, A. C., Williams, J., Sinha, V., Custer, T., Song, W., Johnson, A. M., Axinte, R., Bozem, H., Fischer, H., Pouvesle, N., Phillips, G., Crowley, J. N., Rantala, P., Rinne, J., Kulmala, M.,
Gonzales, D., Valverde-Canossa, J., Vogel, A., Hoffmann, T., Ouwersloot, H. G., de Arellano, J. V. G., and Lelieveld, J.: Summertime total $\mathrm{OH}$ reactivity measurements from boreal forest during HUMPPA-COPEC 2010, Atmos. Chem. Phys., 12, 8257 8270, doi:10.5194/acp-12-8257-2012, 2012.

Novelli, A., Hens, K., Tatum Ernest, C., Kubistin, D., Regelin, E., Elste, T., Plass-Dülmer, C., Martinez, M., Lelieveld, J., and Harder, H.: Characterisation of an inlet pre-injector laser induced fluorescence instrument for the measurement of ambient hydroxyl radicals, Atmos. Meas. Tech. Discuss., 7, 819-858, doi:10.5194/amtd-7-819-2014, 2014.

Oswald, R., Behrendt, T., Ermel, M., Wu, D., Su, H., Cheng, Y., Breuninger, C., Moravek, A., Mougin, E., Delon, C., Loubet, B., Pommerening-Röser, A., Sorgel, M., Pöschl, U., Hoffmann, T., Andreae, M. O., Meixner, F. X., and Trebs, I.: HONO emissions from soil bacteria as a major source of atmospheric reactive nitrogen, Science, 341, 1233-1235, doi:10.1126/science.1242266, 2013.

Ouwersloot, H. G., Vilà-Guerau de Arellano, J., Nölscher, A. C., Krol, M. C., Ganzeveld, L. N., Breitenberger, C., Mammarella, I., Williams, J., and Lelieveld, J.: Characterization of a boreal convective boundary layer and its impact on atmospheric chemistry during HUMPPA-COPEC-2010, Atmos. Chem. Phys., 12, 93359353, doi:10.5194/acp-12-9335-2012, 2012.

Park, J. Y. and Lee, Y. N.: Solubility and decomposition kinetics of nitrous-acid in aqueous-solution, J. Phys. Chem., 92, 6294-6302, doi:10.1021/j100333a025, 1988.

Perner, D. and Platt, U.: Detection of nitrous-acid in the atmosphere by differential optical-absorption, Geophys. Res. Lett., 6, 917920, doi:10.1029/GL006i012p00917, 1979.

Petäjä, T., Mauldin, III, R. L., Kosciuch, E., McGrath, J., Nieminen, T., Paasonen, P., Boy, M., Adamov, A., Kotiaho, T., and Kulmala, M.: Sulfuric acid and $\mathrm{OH}$ concentrations in a boreal forest site, Atmos. Chem. Phys., 9, 7435-7448, doi:10.5194/acp9-7435-2009, 2009.

Raivonen, M., Bonn, B., Sanz, M. J., Vesala, T., Kulmala, M., and Hari, P.: UV-induced $\mathrm{NO}_{\mathrm{y}}$ emissions from Scots pine: could they originate from photolysis of deposited $\mathrm{HNO}_{3}$ ?, Atmos. Environ., 40, 6201-6213, doi:10.1016/j.atmosenv.2006.03.063, 2006.

Ramazan, K. A., Syomin, D., and Finlayson-Pitts, B. J.: The photochemical production of HONO during the heterogeneous hydrolysis of $\mathrm{NO}_{2}$, Phys. Chem. Chem. Phys., 6, 3836-3843, 2004.

Ren, X., Sanders, J. E., Rajendran, A., Weber, R. J., Goldstein, A. H., Pusede, S. E., Browne, E. C., Min, K.-E., and Cohen, R. C.: A relaxed eddy accumulation system for measuring vertical fluxes of nitrous acid, Atmos. Meas. Tech., 4, 2093 2103, doi:10.5194/amt-4-2093-2011, 2011.

Rohrer, F. and Berresheim, H.: Strong correlation between levels of tropospheric hydroxyl radicals and solar ultraviolet radiation, Nature, 442, 184-187, doi:10.1038/nature04924, 2006.

Rummel, U., Ammann, C., Gut, A., Meixner, F. X., and Andreae, M. O.: Eddy covariance measurements of nitric oxide flux within an Amazonian rain forest, J. Geophys. Res., 107, 8050, doi:10.1029/2001JD000520, 2002.

Sander, S. P., Abbatt, J. P. D., Barker, J. R., Burkholder, J. B., Friedl, R. R., Golden, D. M., Huie, R. E., Kolb, C. E., Kurylo, M. J., Moortgat, G. K., Orkin, V. L., and Wine, P. H.: Chemical Kinetics and Photochemical Data for Use in Atmo- 
spheric Studies, Evaluation No. 17, in: JPL Publication 10-6, Jet Propulsion Laboratory, Pasadena, 2011.

Sander, S. P. and Peterson, M.: Kinetics of the reaction $\mathrm{HO}_{2}+\mathrm{O}_{2}+M=>\mathrm{HO}_{2} \mathrm{NO}_{2}+\mathrm{M}$, J. Phys. Chem., 88, 1566-1571, 1984.

Skopp, J., Jawson, M. D., and Doran, J. W.: Steady-state aerobic microbial activity as a function of soil-water content, Soil Sci. Soc. Am. J., 54, 1619-1625, 1990.

Sörgel, M., Regelin, E., Bozem, H., Diesch, J.-M., Drewnick, F., Fischer, H., Harder, H., Held, A., Hosaynali-Beygi, Z., Martinez, M., and Zetzsch, C.: Quantification of the unknown HONO daytime source and its relation to $\mathrm{NO}_{2}$, Atmos. Chem. Phys., 11, 10433-10447, doi:10.5194/acp-11-10433-2011, 2011 a.

Sörgel, M., Trebs, I., Serafimovich, A., Moravek, A., Held, A., and Zetzsch, C.: Simultaneous HONO measurements in and above a forest canopy: influence of turbulent exchange on mixing ratio differences, Atmos. Chem. Phys., 11, 841-855, doi:10.5194/acp11-841-2011, 2011b.

Sörgel, M., Wu, D., Trebs, I., and Held, A.: A comparison of measured HONO uptake and release with calculated source strengths in a heterogeneous forest environment, Atmos. Chem. Phys. Discuss., 15, 2119-2155, doi:10.5194/acpd-15-2119-2015, 2015.

Stemmler, K., Ammann, M., Donders, C., Kleffmann, J., and George, C.: Photosensitized reduction of nitrogen dioxide on humic acid as a source of nitrous acid, Nature, 440, 195-198, 2006.

Stemmler, K., Ndour, M., Elshorbany, Y., Kleffmann, J., D’Anna, B., George, C., Bohn, B., and Ammann, M.: Light induced conversion of nitrogen dioxide into nitrous acid on submicron humic acid aerosol, Atmos. Chem. Phys., 7, 4237-4248, doi:10.5194/acp-7-4237-2007, 2007.

Su, H., Cheng, Y. F., Cheng, P., Zhang, Y. H., Dong, S., Zeng, L. M., Wang, X., Slanina, J., Shao, M., and Wiedensohler, A.: Observation of nighttime nitrous acid (HONO) formation at a nonurban site during PRIDE-PRD2004 in China, Atmos. Environ., 42, 6219-6232, doi:10.1016/j.atmosenv.2008.04.006, 2008a.

Su, H., Cheng, Y. F., Min, S., Dong Feng, G., Zhong Ying, Y., Li Min, Z., Slanina, J., Yuan Hang, Z., and Wiedensohler, A.: Nitrous acid (HONO) and its daytime sources at a rural site during the 2004 PRIDE-PRD experiment in China, J. Geophys. Res.Atmos., 114, D14312, doi:10.1029/2007jd009060, 2008b.

Su, H., Cheng, Y., Oswald, R., Behrendt, T., Trebs, I., Meixner, F. X., Andreae, M. O., Cheng, P., Zhang, Y., and Pöschl, U.: Soil Nitrite as a Source of Atmospheric HONO and OH Radicals, Science, 333, 1616-1618, doi:10.1126/science.1207687, 2011.

Trebs, I., Bohn, B., Ammann, C., Rummel, U., Blumthaler, M., Königstedt, R., Meixner, F. X., Fan, S., and Andreae, M. O.: Relationship between the $\mathrm{NO}_{2}$ photolysis frequency and the solar global irradiance, Atmos. Meas. Tech., 2, 725-739, doi:10.5194/amt-2-725-2009, 2009.

Twigg, M. M., House, E., Thomas, R., Whitehead, J., Phillips, G. J., Famulari, D., Fowler, D., Gallagher, M. W., Cape, J. N., Sutton, M. A., and Nemitz, E.: Surface/atmosphere exchange and chemical interactions of reactive nitrogen compounds above a manured grassland, Agr. Forest Meteorol., 151, 1488-1503, doi:10.1016/j.agrformet.2011.06.005, 2011.

Tyndall, G. S., Orlando, J. J., and Calvert, J. G.: Upper limit for the rate coefficient for the reaction $\mathrm{HO}_{2}+\mathrm{NO}_{2}=>\mathrm{HONO}+\mathrm{O}_{2}$, Environ. Sci. Technol., 29, 202-206, 1995.
VandenBoer, T. C., Brown, S. S., Murphy, J. G., Keene, W. C., Young, C. J., Pszenny, A. A. P., Kim, S., Warneke, C., de Gouw, J. A., Maben, J. R., Wagner, N. L., Riedel, T. P., Thornton, J. A., Wolfe, D. E., Dubé, W. P., Öztürk, F., Brock, C. A., Grossberg, N., Lefer, B., Lerner, B., Middlebrook, A. M., and Roberts, J. M.: Understanding the role of the ground surface in HONO vertical structure: high resolution vertical profiles during NACHTT-11, J. Geophys. Res.-Atmos., 118, 10155-10171, doi:10.1002/jgrd.50721, 2013.

Williams, J., Crowley, J., Fischer, H., Harder, H., Martinez, M., Petäjä, T., Rinne, J., Bäck, J., Boy, M., Dal Maso, M., Hakala, J., Kajos, M., Keronen, P., Rantala, P., Aalto, J., Aaltonen, H., Paatero, J., Vesala, T., Hakola, H., Levula, J., Pohja, T., Herrmann, F., Auld, J., Mesarchaki, E., Song, W., Yassaa, N., Nölscher, A., Johnson, A. M., Custer, T., Sinha, V., Thieser, J., Pouvesle, N., Taraborrelli, D., Tang, M. J., Bozem, H., Hosaynali-Beygi, Z., Axinte, R., Oswald, R., Novelli, A., Kubistin, D., Hens, K., Javed, U., Trawny, K., Breitenberger, C., Hidalgo, P. J., Ebben, C. J., Geiger, F. M., Corrigan, A. L., Russell, L. M., Ouwersloot, H. G., Vilà-Guerau de Arellano, J., Ganzeveld, L., Vogel, A., Beck, M., Bayerle, A., Kampf, C. J., Bertelmann, M., Köllner, F., Hoffmann, T., Valverde, J., González, D., Riekkola, M.-L., Kulmala, M., and Lelieveld, J.: The summertime Boreal forest field measurement intensive (HUMPPA-COPEC-2010): an overview of meteorological and chemical influences, Atmos. Chem. Phys., 11, 1059910618, doi:10.5194/acp-11-10599-2011, 2011.

Wong, K. W., Tsai, C., Lefer, B., Haman, C., Grossberg, N., Brune, W. H., Ren, X., Luke, W., and Stutz, J.: Daytime HONO vertical gradients during SHARP 2009 in Houston, TX, Atmos. Chem. Phys., 12, 635-652, doi:10.5194/acp-12-635-2012, 2012.

Wong, K. W., Tsai, C., Lefer, B., Grossberg, N., and Stutz, J.: Modeling of daytime HONO vertical gradients during SHARP 2009, Atmos. Chem. Phys., 13, 3587-3601, doi:10.5194/acp-13-35872013, 2013.

Yabushita, A., Enami, S., Sakamoto, Y., Kawasaki, M., Hoffmann, M. R., and Colussi, A. J.: Anion-catalyzed dissolution of $\mathrm{NO}_{2}$ on aqueous microdroplets, J. Phys. Chem. A, 113, 48444848, doi:10.1021/jp900685f, 2009.

York, D., Evensen, N. M., Martìnez, M. L., and De Basabe Delgado, J.: Unified equations for the slope, intercept, and standard errors of the best straight line, Am. J. Phys., 72, 367-375, doi:10.1119/1.1632486, 2004.

Zhang, N., Zhou, X., Bertman, S., Tang, D., Alaghmand, M., Shepson, P. B., and Carroll, M. A.: Measurements of ambient HONO concentrations and vertical HONO flux above a northern Michigan forest canopy, Atmos. Chem. Phys., 12, 8285-8296, doi:10.5194/acp-12-8285-2012, 2012.

Zhou, X. L., Gao, H. L., He, Y., Huang, G., Bertman, S. B., Civerolo, K., and Schwab, J.: Nitric acid photolysis on surfaces in low- $\mathrm{NO}_{\mathrm{x}}$ environments: significant atmospheric implications, Geophys. Res. Lett., 30, 2217 doi:10.1029/2003gl018620, 2003.

Zhou, X. L., Zhang, N., TerAvest, M., Tang, D., Hou, J., Bertman, S., Alaghmand, M., Shepson, P. B., Carroll, M. A., Griffith, S., Dusanter, S., and Stevens, P. S.: Nitric acid photolysis on forest canopy surface as a source for tropospheric nitrous acid, Nat. Geosci., 4, 440-443, doi:10.1038/ngeo1164, 2011.

Zhu, C., Xiang, B., Zhu, L., and Cole, R.: Determination of absorption cross sections of surface-adsorbed $\mathrm{HNO}_{3}$ in the $290-330 \mathrm{~nm}$ 
region by Brewster angle cavity ring-down spectroscopy, Chem. Phys. Lett., 458, 373-377, doi:10.1016/j.cplett.2008.04.125, 2008.
Zhu, C. Z., Xiang, B., Chu, L. T., and Zhu, L.: $308 \mathrm{~nm}$ photolysis of nitric acid in the gas phase, on aluminum surfaces, and on ice films, J. Phys. Chem. A, 114, 2561-2568, doi:10.1021/jp909867a, 2010. 